\title{
Tüketici Yenilikçiliği ve Sosyal Onay İhtiyacı Arasındaki İlişkinin İncelenmesi Üzerine Bir Araştırma (A Research on The Examining of The Relationship Between Consumer Innovation and The Need for Social Approval)
}

\author{
Aybike Tuba ÖZDEN \\ a Ondokuz Mayıs Üniversitesi, Samsun Meslek Yüksekokulu, Samsun, Türkiye, aybike.ozden@omu.edu.tr
}

\begin{tabular}{|c|c|}
\hline MAKALE BİLGİSİ & ÖZET \\
\hline $\begin{array}{l}\text { Anahtar Kelimeler: } \\
\text { Tüketici Yenilikçiliği }\end{array}$ & $\begin{array}{l}\text { Amaç - Bu çalışmanın temel amacı, tüketicilerin sosyal onay ihtiyaçları ile yenilikçi eğilimleri } \\
\text { arasındaki ilişkiyi tespit etmek ve pazara yeni ürün sunacak işletmelere öneriler sunabilmektir. }\end{array}$ \\
\hline $\begin{array}{l}\text { Sosyal Onay İhtiyacı } \\
\text { Y Kuşağı } \\
\text { Z Kuşağı } \\
\text { Demografik Özellikler }\end{array}$ & $\begin{array}{l}\text { Yöntem - Bu amaçla Y ve } \mathrm{Z} \text { kuşağına mensup toplam } 402 \text { tüketiciye anket uygulanmıştır. Bu } \\
\text { anketler, kolayda örneklem yoluyla seçilmiş tüketiciler üzerinde yapılmıştır. Ölçeklerden elde edilen } \\
\text { puanlar arasındaki ilişkileri incelemek için Pearson Korelasyon analizi uygulanmıştır. Araştırma } \\
\text { kapsamında, sosyal onay ihtiyacının tüketici yenilikçiliği üzerindeki etkisini belirlemek için } \\
\text { doğrusal regresyon analizleri gerçekleştirilmiştir. }\end{array}$ \\
\hline $\begin{array}{l}\text { Gönderme Tarihi } 2 \text { Haziran } 2019 \\
\text { Revizyon Tarihi } 3 \text { Ağustos } 2019 \\
\text { Kabul Tarihi } 5 \text { Ağustos } 2019\end{array}$ & $\begin{array}{l}\text { Bulgular - Araştırmada elde edilen sonuçlara göre, } Z \text { kuşağı tüketicilerinin sosyal onay ihtiyaç ve } \\
\text { tüketici yenilikçiliği düzeylerinin Y kuşağı tüketicilerine göre daha yüksek olduğu görülmüştür ve } \\
\text { sosyal onay ihtiyaç düzeyi ile tüketici yenilikçiliği arasında anlamlı ve pozitif yönde bir ilişki olduğu } \\
\text { tespit edilmiştir. }\end{array}$ \\
\hline $\begin{array}{l}\text { Makale Kategorisi: } \\
\text { Araştırma Makalesi }\end{array}$ & $\begin{array}{l}\text { Tartışma - İşletmelerin yeni bir ürünü pazara sunarlarken tüketicilerin istek ve ihtiyaçlarını dikkate } \\
\text { alma zorunluluğu bulunmaktadır ve bu zorunluluk, yeni bir üründen beklentilerinin ne olduğunun } \\
\text { anlaşılmasını kolaylaştıran yenilikçi tüketicileri tanıma zorunluluğunu da beraberinde } \\
\text { getirmektedir. Tüketici yenilikçiliği ve bu eğilimi etkileyen faktörlerin tespiti, işletmelerin pazara } \\
\text { sunacakları yeni ürün ile ilgili strateji geliştirmelerini sağlayacak sorulara cevap bulunmasını } \\
\text { kolaylaştırmaktadır. Tüketicilerin, sosyal ortamlardaki etkileşimi ve bu etkileşimden doğan } \\
\text { onaylanma ihtiyacı ve bu ihtiyacın düzeyinin, kişisel ilişkilerini etkilediği gibi tüketim } \\
\text { davranışlarını ve yenilikçi eğilimlerini etkilediği düşünülmektedir. }\end{array}$ \\
\hline
\end{tabular}

\begin{tabular}{l}
\hline ARTICLE INFO \\
\hline Keywords: \\
Consumer Innovation \\
Need For Social Approval \\
Y Generation \\
Z Generation \\
Demographic Characteristics
\end{tabular}

Received 2 June 2019

Revised 3 August 2019

Accepted 5 August 2019

\section{ABSTRACT}

Purpose - The main purpose of this study is to determine the relationship between the social approval needs of consumers and their innovative tendencies and to offer suggestions to the businesses that will offer new products to the market.

Design/methodology/approach - For this purpose, a total of 402 consumers from $\mathrm{Y}$ and $\mathrm{Z}$ generation were surveyed. These surveys were conducted on selected consumers through with convenience sampling method. Pearson Correlation analysis was used to examine the relationships between the scores obtained from the scales. Within the scope of the research, linear regression analyzes were performed to determine the effect of need for social approval on consumer innovation.

Empirical Results - According to the results of the study, it was found that the levels of social approval and consumer innovation of the $Z$ generation consumers were higher than the $Y$ generation consumers and that there was a significant and positive relationship between the level of social approval need and consumer innovation.

Article Classification: Research Article 


\section{Giriş}

Tüketicilerin istedikleri ürüne ve bilgiye kolay ve hızlı ulaşabilmeleri ve artan ürün çeşitliliği, pazarı zorlu bir rekabet alanına çevirmektedir. Yenilikçilik, genellikle teknolojik değişim ile ilişkilendirilmektedir (Fuentes-Blasco vd., 2017). Büyük bir hızla gelişen teknoloji, beraberinde birçok alanı değiştirmekte ve dönüştürmektedir. Örneğin tüketicilerin her zaman ayn ürünü tercih etmemeleri, teknolojik yeniliklerin ve geçişlerin tetiklenmesinde önemli bir rol üstlenmektedir (Tripsas, 2008: 79). Ayrıca teknolojiyle birlikte yaşanılan her yenilik tüketiciyi, dolayısıyla onun beklentilerini, istek ve ihtiyaçlarını değiştirmektedir.

Kimi tüketiciler, yenilikleri hızla içselleştirebiliyorlarken, kimi tüketiciler için bu kolay bir süreç olmamaktadır. Örneğin yeniliklere açık olmanın nesiller arasında farklılıklar gösterdiği düşünülmektedir. Nitekim teknolojinin içine doğan Z kuşağı için yenilikler çok şaşırtıcı olmayabilmektedir. Bu farklılıkların yanı sıra tüketicilerin yenilikleri benimseme süreci; kültür, değer, ilgi gibi faktörlere bağlı olarak da değişebilmektedir. Ancak her tüketici bireysel olarak ele alındığında, her birinin az ya da çok yenilikçi özellikler taşıdığı ve bir şekilde yenilikleri benimsediği söylenilebilir (Hirschman, 1980: 283).

Tüketiciler, hem kişisel hem de yenilikçi özellikleri açısından birbirlerinden farklılaşmaktadırlar ve bu nedenle yenilikleri erken veya geç benimsemektedirler (Kılıçer ve Odabaşı, 2010: 151). Bu bağlamda işletmelerin yeni ürünlerini pazara sunacakları zaman yenilikçi tüketicileri keşfederek bu doğrultuda pazar bölümlendirmelerini yapmaları gerekmektedir. Nitekim yeniliğin değer taşıyabilmesi, yeni olanın tüketicilerin satın alma davranışını kendi lehine çevirmesiyle mümkün olacaktır (Deniz ve Erciş, 2016: 463).

Tüketiciler, satın alma karar süreçlerinde farklı değişkenler nedeniyle yeni ürünleri satın alma kararı vermektedirler (Erciş ve Türk, 2014: 77-78). Tüketiciler yeni ürünleri, belirli bir sosyal kimliği temsil ettikleri için benimseyebilmekte ve satın alabilmektedirler. Sosyal kimlik işlevi olan ürünler, tüketicilerin belirli sosyal gruplarca kabul görmelerini kolaylaştırdığı için tüketicilerin yeniliklere adaptasyonunu arttırabilmektedir (Grewal vd., 2000: 127). Tüm bu nedenlerle sosyal onay ihtiyacının tüketicilerin yenilikçi eğilimlerini etkilediği düşünülmektedir. Yeniliklerin daha hızlı geliştiği günümüz dünyasında tüketici yenilikçiliği ile ilgili yapılan çalışmaların büyük önem taşıdığı düşünülmektedir. Bu nedenle yenilikçi eğilim gösteren tüketicilerin bu eğilim ve davranışlarını etkileyen psikolojik faktörlerin daha spesifik olarak ele alınması gerekmektedir. Pazara sunulacak yeni ürünlerin başarısında etkili olan tüketicilerin başında yenilikçi tüketicilerin geldiği düşünülmektedir. Nitekim işletmeler, yeni ürünün başarısında etkili olan yenilikçi tüketicileri tanımlayarak hedef pazarlarını ve pazarlama faaliyetlerini şekillendirebilirler ve pazarlama karması unsurlarını düzenleyebilirler (Dobre vd., 2009: 21). Dolayısıyla tüketici davranışını etkileyen sosyal onay ihtiyacının, tüketici yenilikçiliği ile ilişkisinin tespit edilmesinin işletmelerin pazar bölümlendirmeleri ve hedef pazar belirleyerek doğru stratejiler geliştirebilmeleri açısından önem taşıdığı düşünülmektedir. Ayrıca $Y$ ve $Z$ kuşağı tüketicilerinin yenilikçi eğilimlerini etkileyen unsurların değerlendirilmesi, günümüzün büyük bir kesimini oluşturan bu tüketicilerin satın alma davranışlarının analiz edilmesi açısından da önem taşımaktadır. Nitekim yenilikçi tüketiciler, yeni ürünleri satın alma noktasında daha istekli olduklarından diğer tüketicilere referans olmakta önemli bir rol üstlenmektedirler. Sosyal onay ihtiyaçları ve yenilikçi eğilimleri tespit edilen tüketicilere yönelik yapılacak tutundurma çalışmalarının, bu tüketicilerin sadakat ve memnuniyet düzeylerinin tespitinin ve kullandıkları ürüne ilişkin işletmelerin alacakları geri bildirimlerin yeni ürünlerin pazarda daha başarılı olmasını sağlayacağı düşünülmektedir. Bu doğrultuda bu çalışmada; sosyal onay ihtiyacının ve tüketicilerin demografik özelliklerinin tüketici yenilikçiliği ile ilişkisini tespit etmek, işletmelere bu doğrultuda öneriler sunmak ve ilgili literatüre katkıda bulunmak amaçlanmaktadır.

\section{Kavramsal Çerçeve}

\subsection{Tüketici Yenilikçiliği}

Yenilik kavramı, yeni bir fikri ya da bilgiyi satılabilir veya geliştirilebilir bir ürüne dönüştürmek olarak tanımlanabilir (Alan ve Yeloğlu, 2013: 18). Türk Dil Kurumu, yenilik kavramını; "yeni olma durumu", yenilikçi kavramını ise "yenilikten yana olan" olarak tanımlanmaktadır (TDK, 2019). Dolayısıyla tüketici yenilikçiliği kavramı, yeni bir ürünü satın almaktan yana olan tüketicileri tanımlamak için kullanılabilir. Yeni bir ürün, mevcut ürüne çeşitli özellikler ekleyerek revize edilmesi olabileceği gibi, daha önce hiç yapılmamış veya düşünülmemiş bir ürünün yaratılması da olabilir. 


\section{A. T. Özden 11/3 (2019) 1537-1558}

Tüketici yenilikçiliği, tüketicilerin yenilikleri benimseme eğilimleridir denilebilir (Tellis vd., 2009: 1). Bir başka tanıma göre tüketici yenilikçiliği, tüketicilerin yeni ürünlere ve henüz kullanmadıkları markalara sahip olmayı isteme eğilimidir (Jordaan ve Simpson, 2006: 33). Midgley ve Dowling'a (1978) göre ise tüketici yenilikçiliği, tüketicilerin yeni ürünleri daha çabuk ve daha sık satın alma eğilimini diğer tüketicilere göre daha çok göstermeleridir ve bu araştırmacılar, tüketicilerin başka tüketicilerin deneyimlerinden bağımsız olarak yenilik kararı almalarının doğuştan geldiğini savunmaktadırlar. Tüketici yenilikçiliğini bir eğilim olarak değil bir davranış olarak tanımlayan araştırmacılar da mevcuttur. Örneğin Cestre ve Darmon'a (1988) göre, tüketici yenilikçiliği, yeni bir ürünü erken satın alma davranışıdır. Tüketici davranışı açısından iki farklı yenilikçi tipi olduğu söylenilebilir (Madran ve Esen, 2002: 141): Gelişime açık yenilikçilik, tüketicilerin yeniliklerin algısal ve davranışsal niteliklerini kavramaları iken spesifik yenilikçilik bir alana veya ürün kategorisine özgü ilgi alanındaki yeniliklere ayak uydurmak ve bu yenilikler hakkında bilgi sahibi olmaktır. Tüketici yenilikçiliğinin tüketicilerin bilişsel ve duygusal düzeylerinde 3 farklı şekilde oluştuğu (Okutan vd., 2013: 120-121):

- Yeni ürünler hakkında bilgi toplama ve araştırma yapma,

- Yeni ürünlerin tüketiciler tarafından kabullenilmesi,

- Yeni ürünlerin kullanımında farklı kullanım şekillerinin ve amaçlarının olduğunun keşfedilmesi.

Tüketici yenilikçiliği tanımlarının farklılaşmasından da anlaşılacağı üzere tüketici yenilikçiliğinin farklı boyutlarla ele alındığı görülmektedir. Bartels ve Reinder (2011), tüketici yenilikçiliğini 3 boyutta ele almışlardır:

- Kişisel Yenilikçilik (İçsel Yenilikçilik- Innate Innovativeness/II): Kişilik özelliklerine göre tüketici yenilikçiliği, tüketicilerin yeni ürün satın almaları ile kişilik yapılarının ilintili olması yaklaşımıdır. Vandecasteele ve Geuens'a göre (2010) yenilikçiliğin bu boyutu soyut, içsel ve gözlemlenemeyen bir olguyu işaret etmektedir. Açık fikirli, meraklı, yaratıcı, yeni deneyimlere açık olma gibi kişilik özelliklerine sahip tüketicilerin yenilikçi olduğu düşünülebilir. Tüketicilerin yenilikçilik arayışı, doğuştan gelen kişilik özelliklerinin yanında çevre şartlarından da etkilenmektedir (Hirschman, 1980).

- İlgi Alanı (Ürün Temelli Yenilikçilik-Domain Specific Innovativenes/DSI): Tüketicilerin ilgi alanları, yenilikçilik eğilimlerini etkileyebilmektedir. Örneğin bir ürün grubuna ilgi gösteren tüketici, o ürün grubunu daha sık kullanmaktadır ve bu tüketicinin ürün grubuna ait bilgi düzeyi daha yüksek olmaktadır (Goldsmith ve Newell, 1997: 164). Dolayısıyla o tüketicinin ilgi duyduğu ürüne ilişkin yenilikleri takip etmesi beklenilen bir davranış olabilir. Tüketicilerin bu yenilikçilik eğilimleri ilgi ve bilgi düzeylerine göre değişiklik göstermektedir (Goldsmith ve Hofacker, 1991: 210).

- Yenilikçi Davranış (Innovative Behavior/IB): Gerçekleştirilmiş yenilikçilik olarak da isimlendirilmektedir. Yeni ürünlerin satın alınması, gerçekleşmiş yenilik arayışı ve kullanım yenilikçiliği olarak ifade edilmektedir (Akdoğan ve Karaarslan, 2013: 6).

Vandecasteele ve Geuens (2010), yenilikçi tüketicilerin referans gruplarının objektif olmayan yorumlarından daha az etkilendiklerini belirtmektedirler. Araştırmacılar tüketici yenilikçilik ölçeklerinde yenilikçi satın almanın motivasyon kaynaklarının çoğunun görmezden gelindiğini, tüketici ve ürün ilişkisinin daha iyi anlaşılabilmesi için çok boyutlu ve farklı motivasyon kaynaklarının dahil edildiği bir tüketici yenilikçiliği ölçeğine ihtiyaç duyulduğunu belirtmektedirler. Tüketici yenilikçiliğinin temelinde 4 boyut/motivasyon bulunmaktadır (Vandecasteele ve Geuens, 2010):

- İşlevsel Yenilikçilik: Tüketicilerin zaman tasarrufu sağladığı, daha fazla konfor ve işlevselliği olduğu veya işlerini daha kolaylaştırdığı için yeni ürünleri satın almak istemeleri olarak açıklanabilir.

- Hedonik Yenilikçilik: Tüketicilerin, kendilerini daha heyecanlı, canlı veya mutlu hissetmek için yeni bir ürünü satın alarak haz duygusu yaşamak istemeleri şeklinde açıklanabilir.

- Sosyal Yenilikçilik: Tüketicilerin diğer tüketicilerden farklı olma veya daha üstün olabilme nedenleriyle yeni ürünler satın alarak başkalarını etkileme veya saygınlık kazanma ihtiyaçlarını giderme istekleri olarak açıklanabilir. 


\section{A. T. Özden 11/3 (2019) 1537-1558}

- Bilişsel Yenilikçilik: Tüketicilerin bilgi düzeylerini veya yeteneklerini geliştirme ihtiyaçları nedeniyle yeni ürünler satın alarak sorun çözme odaklı alışveriş yapmaları olarak açıklanabilir.

Tüketici yenilikçiliği ile ilgili yapılan araştırmalara bakıldığında; Venkatraman (1991), tüketici yenilikçiliğinin demografik özelliklerine göre farklılaştığını belirtmektedir. Citrin vd. (2000), tüketici yenilikçiliğinin online alışverişi benimseme üzerinde etkisi olduğunu saptamışlardır. Lassar vd. (2005), tüketici yenilikçiliğinin internet bankacılığına uyum üzerinde etkisi olduğunu belirtmektedirler. Im vd. (2007), tüketicilerin yaş ve eğitim düzeylerinin kişisel yenilikçilik üzerinde etkisi olduğunu belirtmişlerdir. Wang ve Yang (2008), yapmış oldukları araştırmalarında tüketici yenilikçiliğinin online alışverişin benimsenmesi üzerinde anlamlı bir etkisi olduğunu belirtmektedirler. Persaud ve Azhar (2012), mobil pazarlamada erkek tüketicilerin kadın tüketicilere oranla yenilikçi pazarlama tekliflerine daha açık olduklarını tespit etmişlerdir. Stock vd. (2016), deneyime açık tüketicilerin yeni ürün satın alma fikrine daha yatkın olduklarını tespit etmişlerdir. Hasan vd. (2019), tüketicilerin sadece işlevsellik ve ekonomik ihtiyaçlarla motive olmadıklarını belirtmektedirler.

Madran ve Esen (2002), yaptıkları araştırma ile yenilikleri benimseyen tüketicileri yenilikçiler, erken çoğunluk ve geciken çoğunluk olarak sınıflandırmışlardır. Uzkurt (2007), kişisel değerler ve yenilikleri benimseme arasında istatistikî bir ilişki olduğunu tespit etmiştir. Aydın (2009), yenilikçi kişisel özelliklerin cep telefonu kullanımında tüketici yenilikçiliğini pozitif yönde etkilediğini tespit etmiştir. Kılıçer ve Odabaşı (2010), Bireysel Yenilikçilik Ölçeği'nin Türkçe uyarlamasını yapmışlardır. Eryiğit ve Kavak (2011), tüketici yenilikçiliğinin tutumsal ve davranışsal uyumunu incelemişler ve yenilikçi tutumun bireyi, davranışa yönlendirmediği sonucuna ulaşmışlardır. Demirelli (2014), tüketici yenilikçiliği ve gönüllü sade yaşam tarzı arasında ilişki olduğunu tespit etmiştir. Erciş ve Türk (2014), yaptıkları araştırma ile kişisel değerlerin hedonik ve sosyal yenilikçilik ile ilgili her iki yenilikçilik boyutunun birbirleri üzerinde etkisi olduğunu tespit etmişlerdir. Özçiftçi (2015), cinsiyetin ve aile gelirinin kişisel yenilikçilik üzerinde etkisi olduğunu tespit etmiştir. Deniz ve Erciş (2016), yaptıkları araştırmada kişisel yenilikçiliğin öz saygı ve risk alma özelliklerinden, ürün temelli yenilikçiliğin ise fikir liderliği ve uzmanlık faktörlerinden etkilendiğini belirtmektedirler. Kavak vd. (2017), akıllı telefon kullanıcılarından yeni ürünü ilk benimseyenlerin bütüncül düşündüğünü, daha geç benimseyenlerin ise analitik düşündüğünü belirtmektedirler. Esen vd. (2018), bireysel yenilikçiliğin ve güven duygusunun online alışveriş davranışını olumlu yönde etkilediği sonucuna ulaşmışlardır.

Yapılan araştırmalara bakıldığında tüketici yenilikçiliğini etkileyen çeşitli unsurlar üzerinde durulduğu ve bu unsurların yenilikçi tüketici davranışını ne düzeyde ve şekilde etkilediğinin tespit edilmeye çalışıldığı görülmektedir. Bu çalışmada, günümüzün önemli bir kesimini oluşturmakta olan $\mathrm{Y}$ ve $\mathrm{Z}$ kuşağ1 tüketicilerinin yenilikçi davranış düzeylerinin, tüketici davranışını etkileyen psikolojik faktörlerden sosyal onay ihtiyacı ve demografik özellikleri ile ilişkisi üzerinde durulacaktır.

Tüketici yenilikçiliğini farklı ölçekler kullanarak ölçen çeşitli araştırmalar mevcuttur. Goldsmith ve Hofacker (1991), ürün temelli yenilikçiliği ölçen DSI Ölçeği'ni geliştirmişlerdir. Midgley ve Dowling (1978) Kişisel Yenilikçilik Ölçeği'ni geliştirmişlerdir. Manning vd. (1995), bağımsız karar verme ve yenilik arayışı olan iki boyutlu ve doğuştan yenilikçiliği ölçen bir ölçek geliştirmişlerdir. Bu araştırmada ise tüketici yenilikçiliğini, yukarıda belirtilen dört boyutu ile ölçen, Vandecasteele ve Geuens (2010) tarafından oluşturulan, Bülbül ve Özoğlu (2014) tarafından da Türkiye'de geçerliliği ve güvenilirliliği onaylanmış “Güdülenmiş Tüketici Yenilikçiliği Ölçeği" kullanılmıştır. Bu ölçek, tüketici yenilikçiliğini sadece tüketicilerin kişilik özelliklerine veya ürüne özgü özelliklere bağlı kalmadan çok boyutlu değerlendirebilmesi açısından önem taşımaktadır (Bülbül ve Özoğlu, 2014: 45). Nitekim güdülenmiş tüketici yenilikçiliğinin tüm boyutlarıyla değerlendirilmemesi, yenilikçi tüketicilere ilişkin yetersiz veri sunacağından tüketici yenilikçiliğinin işlevsel, hedonik, bilişsel ve sosyal yenilikçilik boyutlarıyla bir bütün olarak ele alınması ve değerlendirilmesi gerektiği düşünülmektedir. Kavak vd. (2016) Güdülenmiş Tüketici Yenilikçiliği Ölçeği'ni kullanarak yapmış oldukları araştırma ile ölçeğin yeterli güvenilirliğe sahip olduğunu belirtmektedirler.

\subsection{Sosyal Onay İhtiyacı}

Günümüz tüketim toplumlarında tüketiciler istek ve ihtiyaçlarını karşılamak dışında da tüketim davranışı gösterebilmektedirler. Bir gruba ait olma duygusunu tatmin etmek isteyen tüketiciler, sosyal ortamların gerektirdiği çeşitli normlara uyum sağlayabilmelidirler. Grup üyelerinin, o gruba ait belirli davranışları 
yapmaları, kültürel veya ahlaki değerlerini benimsemeleri ile orantılı şekilde tüketiciler o gruba dahil olabilirler ya da dışlanabilirler. Bu doğrultuda sosyal onay ihtiyacı, tüketicilerin aidiyet ihtiyacı için önemli bir güdü olarak karşımıza çıkmaktadır ve sosyal onay sağlayan sosyal kimliklerin en hızlı tanımlayıcıları günümüzde tüketicilerin tüketim biçimleridir (Kadığlu, 2013: 106).

Sosyal onay ihtiyacı, bireylerin diğer bireylerin onayını arzulaması ve onaylanmamaktan kaçınması olarak tanımlanmaktadır (Leite ve Beretvas, 2005:141). Diğer bireylerin onayına ihtiyaç duyan bireyler, kendi istek ve ihtiyaçlarından bağımsız bir şekilde ait olmak istedikleri grup üyelerinin beklentilerine uygun davranışlar sergileme eğilimi gösterebilmektedirler. Örneğin; Leibenstein (1950:189), bazı tüketicilerin sadece diğer tüketiciler satın alıyor diye bir ürüne ilgi duyup o ürünü satın alabileceklerini belirtmektedir. Tüketicilerin bu davranışında diğer tüketicilerle ilişkide kalabilme dürtüsü dışında o tüketicilerin onaylarını alabilme isteklerinin de etkili olduğu düşünülmektedir. Dolayısıyla tüketicilerin sosyal onay ihtiyaçları nedeniyle lüks tüketim yapabildikleri gibi yeni ürünleri satın alma eğilimi gösterdikleri de söylenilebilir.

West'e göre (2013) sosyal onay ihtiyacı yüksek olan bireyler; diğer bireylerin düşünceleriyle ilgili aşırı kaygı gösteren, değer duygularının sosyal onaya dayalı olduğu, övgü beklentisinde olan, mükemmeliyetçi, yardımsever ve reddetmekte zorlanan bireylerdir. Sosyal onay ihtiyacı düşük bireylerin ise başka bireylerin düşüncelerinden çabuk etkilenmeyen, onaylamadıkları fikirleri reddedebilen ve özgüvenleri daha yüksek bireyler oldukları söylenilebilir.

Sosyal onay ihtiyacı, tüketicilerde başkalarına kendilerini beğendirmek ve onları şaşırtmak gibi isteklerin oluşmasına sebep olabilmektedir. Tüketici yenilikçiliğinin sosyal yenilikçilik boyutunda olan tüketiciler, farklı olmak ve kendilerini diğer tüketicilerden farklı gösterecek şeyleri denemek istemektedirler (Erciş ve Türk, 2014:78). Yeni ürünleri satın almak tüketiciler için statü kazanma, prestij elde etme veya ait olma duygularını kazandıran bir süreç olarak değerlendirilebilmektedir. Nitekim sosyal onay ihtiyacıyla ilgili ele alınan değişkenlerin bazıları mükemmeliyetçilik, sosyal kaygı, mutluluk ve benlik şeklinde sıralanabilir (Karaşar ve Öğülmüş, 2016a). Bu bağlamda tüketiciler duygusal amaçlarını karşılayan ve tatmin olmalarını sağlayan yenilikçi eğilimler gösterebilmektedirler ve lüks ürünler satın alarak eğlence ve heyecan yaşamak istemektedirler (Venkatraman ve Price, 1990).

$\mathrm{Bu}$ araştırmada tüketicilerin sosyal onay ihtiyaç düzeyleri; Karaşar ve Öğülmüş (2016b) tarafından kültürümüze uygun olacak şekilde geliştirilen, geçerlik ve güvenirlik analizi yapılan Sosyal Onay İhtiyacı Ölçeği kullanılarak ölçülmüştür. Bu ölçek, 3 alt boyuttan oluşmaktadır (Karaşar ve Ögü̈lmüş, 2016b: 95):

- Başkalarının Yargılarına Duyarlılık: Bireylerin başka bireyler tarafından onay ve takdir beklentilerini ve önem derecesini ifade etmektedir.

- Sosyal Geri Çekilme: Başkaları tarafından onaylanmama ve reddedilme korkusunu, başkalarının beklentilerine göre karar alma çabasını ve olumsuz yönlerin gizlenilmesini ifade etmektedir.

- Olumlu İzlenim Bırakma: Başkaları tarafından onaylanılmadığında ve eleştiri alınıldığında kendini değersiz hissetme duygusunu ifade etmektedir.

\subsection{Y ve Z Kuşağı Tüketicilerinde Tüketici Yenilikçiliği}

Tüketici profilini belirleyebilmenin en belirgin faktörlerinden birinin tüketicilerin demografik özellikleri olduğu söylenilebilir. Demografik özelliklerden biri olan yaş faktörü ise, işletmelerin tüketicilerin istek ve ihtiyaçlarını anlayabilmeleri ve isabetli pazar bölümlendirme yapabilmeleri açısından önem taşımaktadır. Araştırmacılar, belirli yaş aralıklarını ele alarak benzer özellikler gösteren tüketicileri tanımlayabilmektedirler. Bu noktada kuşaklar ve gösterdikleri özellikler ön plana çıkmaktadır. Kuşak, 25-30 yıllık yaş kümelerinden oluşan kişilerin oluşturduğu gruplar olarak tanımlanabilir (TDK, 2019). Aynı kuşağa mensup olan bireyler; benzer tarihsel olayları yaşamış, benzer sosyo-ekonomik süreçlere şahitlik etmiş, yaşadıkları dönemin tüketim alışkanlıklarına ilişkin benzer beklentileri olan tüketiciler olarak değerlendirilebilirler. Her kuşak, kendine özgü karakteristik özellikler taşımaktadır ve benzer alışkanlıklara sahiptir.

Bu çalışmada, Y ve Z kuşağına mensup tüketicilerin sosyal onay ihtiyaç düzeyleri ile tüketici yenilikçilik düzeyleri arasındaki ilişki ele alınacaktır. Kuşak sınıflandırmasına göre $Y$ kuşağına mensup tüketiciler 19801999 yılları arasında doğan tüketicilerden oluşmaktadır; Z kuşağına mensup tüketiciler ise 2000 yılı ve 


\section{A. T. Özden 11/3 (2019) 1537-1558}

sonrasında doğan tüketicilerden oluşmaktadır (DeVaney, 2015: 11). Y kuşağı; kendisinden önceki kuşağa göre teknoloji alanında daha üstün, dolayısıyla teknoloji tutkunu, özgürlüklerine düşkün, kitlesel tüketimden ziyade kişiye özel olanı seven ve girişimci ruhu olan tüketicilerden oluşmaktadır (Yaşa ve Bozyiğit, 2012: 33). Z kuşağı ise teknoloji alanında yaşanan gelişmelerle birlikte tüketim kararlarında tüm kuşakları etkileyebilecek güce sahip, teknolojiye bağımlı, aceleci, internet ortamına hâkim ve anlık tüketim yapan tüketicilerden oluşmaktadır (Altıntuğ, 2012: 206). Y kuşağının teknolojiyle büyüyen, Z kuşağının ise teknolojinin içine doğan nesiller oldukları söylenilebilir. Her iki kuşaktan olan tüketiciler için, günümüzün ve geleceğin önemli tüketici profillerini oluşturdukları söylenilebilir.

Tüketici yenilikçiliği ile ilgili yapılan çalışmalara bakıldığında elde edilen sonuçlar açısından farklılıklar olduğu görülmektedir. Örneğin Akdoğan vd. (2018), Goldsmith vd. (1999), Vandecasteele ve Geuens (2010), tüketici yenilikçiliği ve yaş arasında ilişki olmadığını tespit edilmişlerdir. Steenkamp vd. (1999) ise yapmış oldukları araştırma ile yaş arttıkça tüketici yenilikçiliğinin azaldığını tespit etmişlerdir. Yapılan başka bir çalışmada yaş ile gelir düzeyinin yeni ürüne uyum sağlama süreci arasında güçlü bir ilişki olduğu, yaş arttıkça yenilikçi eğilimin azaldığının tespit edildiği görülmektedir (Im vd., 2003). Im, vd. (2007) yapmış oldukları araştırmada yaş faktörünün kişisel yenilikçilik üzerinde etkisi olduğunu görmüşlerdir. Eryiğit ve Kavak (2008), 18-30 yaş arası gelecek odaklı kadın tüketicilerin yeniliği benimsememe olasılıklarının geç benimseme olasılıklarından daha yüksek olduğunu tespit etmişlerdir. Kavak vd. (2016), yapmış oldukları araştırma ile 18-24 yaş aralığındaki tüketiciler ile 31-35 yaş aralığındaki tüketicilerin yenilikçilik düzeyleri arasında anlamlı bir farklılık olduğunu, 18-24 yaş aralığındaki tüketicilerin hedonik güdülerinin 31-35 ve 40 yaş üzeri olan tüketicilerden daha yüksek olduğunu tespit etmişlerdir. Araştırmalarda elde edilen bu bulgular ışığında tüketici yenilikçiliğinin kuşaklar arasında farklılaştığı düşünülmektedir. Nitekim yenilikçi tüketiciler; genellikle cesur, teknoloji odaklı, hedonik güdülerden etkilenen, markaya ve statüye önem veren, parasal kaygısı düşük genç tüketicilerden oluşmaktadır (Kavak vd., 2017: 186). Bu çalışmada, sosyal onay ihtiyacı ve tüketici yenilikçiliği arasındaki ilişki $Y$ ve $Z$ kuşağı tüketiciler açısından değerlendirilecektir. $Z$ kuşağ 1 tüketicilerinin, sosyal onay ihtiyaçlarının ve tüketici yenilikçiliği düzeylerinin kendilerinden önceki nesil olan Y kuşağına göre daha yüksek düzeyde olduğu düşünülmektedir. Bu duruma $\mathrm{Z}$ kuşağının online ortama hakimiyetinin ve sosyal medya ile önceki nesile göre çok daha erken tanışmış olmalarının sebep olabileceği düşünülmektedir. Nitekim Z kuşağı, teknolojinin büyük bir hızla ilerlediği ve sosyal hayatlara sirayet ettiği dönemde doğmuş tüketicilerden oluşmaktadır, yeniliklere çok alışkındırlar ve karşılaştıkları bu yeniliklerden de çabuk sıkılabilmektedirler.

\section{Araştırmanın Yöntemi}

\subsection{Araştırmanın Amacı ve Önemi}

Yenilikçi tüketiciler, yeni olan ürünleri deneme ve satın alma konusunda çok istekli olabilmektedirler. Bu tüketiciler denedikleri ürünlerin diğer tüketicilere tanıtılmasında etkin ve kritik bir rol üstlenmektedirler (Köker ve Maden, 2017: 838). Ayrıca yenilikçi tüketiciler, pazara açılacak yeni bir ürüne ilişkin diğer tüketicilerin istek ve beklentilerine dair önemli doneler verebilmektedirler. Bu nedenle tüketici yenilikçiliğini etkileyen faktörlerin tespit edilmesi; işletmelerin tüketicileri daha iyi tanıyarak onların istek ve ihtiyaçlarını en iyi şekilde karşılamalarında, isabetli pazar seçiminde, doğru pazar bölümlendirmede ve açıldıkları pazarda süreklilik kazanabilmelerinde önem taşımaktadır. Dolayısıyla bu araştırmanın amacı, sosyal onay ihtiyacının ve tüketicilerin demografik özelliklerinin tüketici yenilikçiliği ile ilişkisini tespit etmek, işletmelere bu doğrultuda öneriler sunmak ve ilgili literatüre katkıda bulunmaktır.

\subsection{Araştırmanın Hipotezleri ve Modeli}

Tüketici yenilikçiliği, deneyime açıklı gibi kişisel özelliklerle ilişkili bir kavramdır (Kılıçer ve Odabaşı, 2010). Sosyal bir varlık olan bireylerin etkili ilişkiler geliştirebilmeleri için sosyal onaya ihtiyaçları bulunmaktadır (Karaşar ve Ögülmüş, 2016b). Clark ve Goldsmith (2006), yapmış oldukları araştırmada tüketici yenilikçiliğinin, kişilerarası etkileşime duyarlılık ile ilişkili olduğunu tespit etmişlerdir. Dolayısıyla kişilerarası etkileşimin önemli bir parçasını oluşturan sosyal onay ihtiyacının tüketici yenilikçiliğini etkilediği düşünülmektedir. Bu bağlamda;

H1:Sosyal onay ihtiyacı ve tüketici yenilikçiliği arasında anlamlı bir ilişki bulunmaktadır.

H1a: Başkalarının yargılarına duyarlılık, işlevsel yenilikçilik üzerinde etkilidir. 


\section{A. T. Özden 11/3 (2019) 1537-1558}

H1b. Sosyal geri çekilme, işlevsel yenilikçilik üzerinde etkilidir.

H1c. Olumlu izlenim bırakma, işlevsel yenilikçilik üzerinde etkilidir.

H1d. Başkalarının yargılarına duyarlılık, hedonik yenilikçilik üzerinde etkilidir.

H1e. Sosyal geri çekilme, hedonik yenilikçilik üzerinde etkilidir.

H1f. Olumlu izlenim bırakma, hedonik yenilikçilik üzerinde etkilidir.

H1g. Başkalarının yargılarına duyarlılık, sosyal yenilikçilik üzerinde etkilidir.

H1h. Sosyal geri çekilme, sosyal yenilikçilik üzerinde etkilidir.

H11. Olumlu izlenim bırakma, sosyal yenilikçilik üzerinde etkilidir.

H1i. Başkalarının yargılarına duyarlılık, bilişsel yenilikçilik üzerinde etkilidir.

H1j. Sosyal geri çekilme, bilişsel yenilikçilik üzerinde etkilidir.

H1k. Olumlu izlenim bırakma, bilişsel yenilikçilik üzerinde etkilidir.

Tüketicilerin yaşı, yaşadığı bölge gibi demografik özellikleri ile kişilik, sosyo-ekonomik ve kültürel özellikleri yeniliği benimseme düzeylerini etkilemektedir (Daghfous vd., 1999: 314; Kumar, 2014: 6). Bu doğrultuda;

H2: Tüketici yenilikçiliği ile tüketicilerin demografik özellikleri arasında anlamlı bir ilişki bulunmaktadır.

H2a: Y ve Z kuşağı tüketicilerinin yenilikçilik düzeyleri anlamlı bir farklılık göstermektedir.

H2b: Tüketici yenilikçiliği cinsiyete göre anlamlı bir farklılık göstermektedir.

H2c: Tüketici yenilikçiliği eğitim seviyesine göre anlamlı bir farklılık göstermektedir.

H2d: Tüketici yenilikçiliği gelir durumuna göre anlamlı bir farklılık göstermektedir.

Etkili ve yakın ilişkiler kurulabilmesi için hissedilen sosyal onay ihtiyaç düzeyleri bireyler arasında farklılıklar göstermektedir (Karaşar ve Öğ̈̈lmüş, 2016b). Masterson (1971) sosyal onay ihtiyaç düzeylerinin cinsiyete göre farklılaştığını belirtmektedir. Twenge ve Campbell (2008) ise Y kuşağı tüketicilerinin sosyal onay ihtiyaç düzeylerinin düşük olduğunu belirtmektedirler. Bu bağlamda;

H3: Tüketicilerin sosyal onay ihtiyaç düzeyleri ile tüketicilerin demografik özellikleri arasında anlamlı bir ilişki bulunmaktadır.

H3a: Y ve Z kuşağı tüketicilerinin sosyal onay ihtiyaç düzeyleri anlamlı bir farklılık göstermektedir.

H3b: Tüketicilerin sosyal onay ihtiyaç düzeyleri cinsiyete göre anlamlı bir farklılık göstermektedir.

H3c: Tüketicilerin sosyal onay ihtiyaç düzeyleri eğitim seviyesine göre anlamlı bir farklılık göstermektedir.

H3d: Tüketicilerin sosyal onay ihtiyaç düzeyleri gelir durumuna göre anlamlı bir farklılık göstermektedir.

Bu hipotezler doğrultusunda araştırmanın modeli şekil 1'deki gibidir.

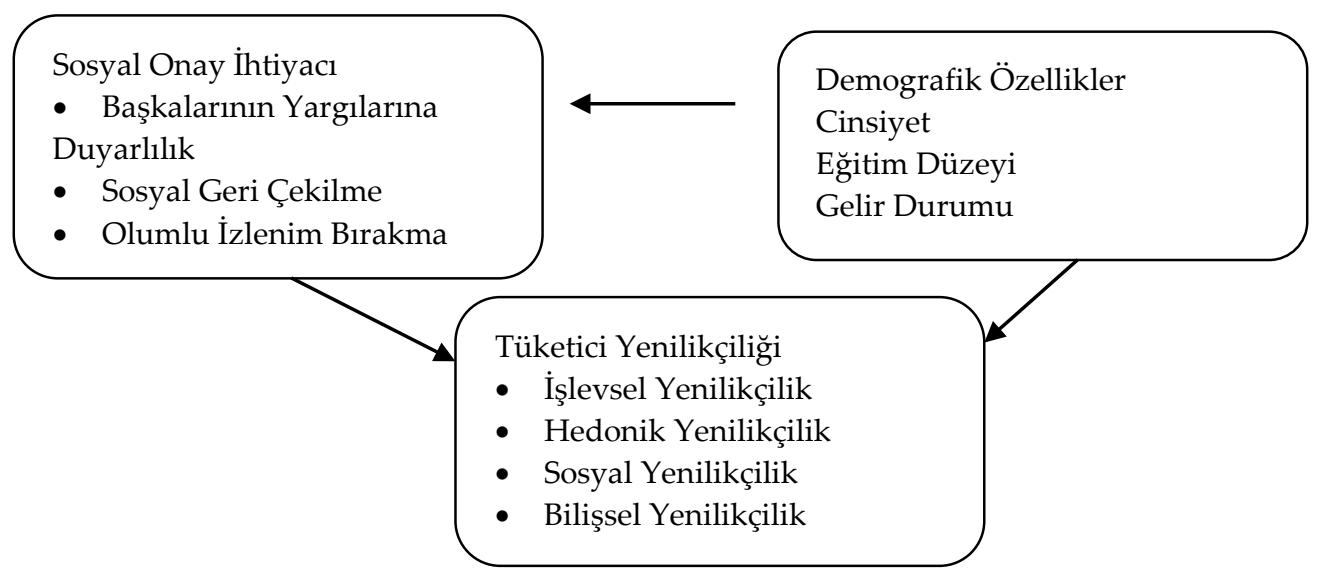

Şekil 1. Araştırmanın Modeli 


\subsection{Araștırmanın Örneklemi}

18 Ocak- 20 Mart 2019 tarihleri arasında Ankara ve Samsun'da uygulanan anketler, kolayda örneklem yoluyla seçilmiş tüketiciler üzerinde yapılmıştır. 1980 ve sonrası doğumlu oluşan tüketicilerden öğrencilere, akademisyenlere ve çalışanlara; Ankara'daki Etimesgut ilçesinde yer alan lise öğrencilerine ve öğretmenlerine yüz yüze anket yapılarak elde edilen cevaplar online ortama aktarılmıştır. Lise ve üniversite öğrencilerinden edinilen mail adreslerine, anket formunun dijital ortamda oluşturulan anket linki postalanarak kullanıcıların doldurulması sağlanmıştır Ayrıca anket formu online olarak çeşitli sosyal medya platformlarında paylaşılmıştır. Online ve yüz yüze yapılan anketler ile toplamda 426 tüketiciye ulaşılmış, hatalı doldurulan, tüm sorulara aynı cevapları veren ve yarım bırakılan anketlerin elenmesi sonucu toplam 402 anket değerlendirmeye alınmıştır.

\subsection{Veri Toplama Yöntemi ve Araçları}

Bu çalışmada, anket yöntemiyle veriler toplanmıştır. Anket formunun birinci bölümünde Vandecasteele ve Geuens'in (2010) tarafından oluşturulan Güdülenmiş Tüketici Yenilikçiliği Ölçeği kullanılmıştır. Ölçek 20 ifadeden oluşmaktadır ve Bülbül ve Özoğlu (2014) tarafından Türkiye'de geçerlilik ve güvenilirliği onaylanmıştır. Anket formunun ikinci bölümü Karaşar ve Öğülmüş (2016b) tarafından kültürümüze uygun olacak şekilde geliştirilen Sosyal Onay İhtiyacı Ölçeği kullanılmıştır. Ölçek 25 ifadeden oluşmaktadır. Ölçeklerde yer alan ifadeler 5'li Likert ölçeğinde sorulmuştur. Likert ölçeğinde değerlendirme (1) Kesinlikle Katılmıyorum, (2) Katılmıyorum, (3) Fikrim Yok, (4) Katılıyorum, (5) Kesinlikle Katılıyorum şeklindedir. Anket formunun son bölümü tüketicilerin cinsiyetlerine, yaşlarına, eğitim durumlarına ve gelir düzeylerine ait bilgilerin olduğu kişisel bilgiler kısmından oluşmaktadır.

\subsection{Geçerlik ve Güvenirlik Çalışması Sonuçları}

Güdülenmiş Tüketici Yenilikçiliği Ölçeği'nin ve Sosyal Onay İhtiyacı Ölçeği'nin geçerliğini incelemek için doğrulayıcı faktör analizi uygulanmıştır. Yapısal eşitli modeli türü olan doğrulayıcı faktör analizi, gözlenen ve gizli değişkenler arasındaki ilişkileri belirleme fırsatı sunmaktadır. Ölçme araçlarının yapı geçerliğinin belirlenmesinde bu analiz önemli bir yere sahiptir. Doğrulayıcı faktör analizi ölçme aracının faktör yapısının eldeki veriler ile ne derece uyumlu olduğu hakkında bilgi vermektedir (Kline, 2011). Doğrulayıcı faktör analizinde test edilen modelin uyum düzeyini belirlemek için uyum iyiliği değerleri hesaplanmaktadır.

Güdülenmiş Tüketici Yenilikçiliği Ölçeği'nin doğrulayıcı faktör analizi ile hesaplanan, standardize edilmiş tahmin sonuçlarına göre, modelin istatistiksel olarak anlamlı olduğu ve modele ait değerlerin uyum kriterlerini karşıladığı anlaşılmıştır. Bu ölçek, dört faktörlü yapısı ile eldeki veriler ile genel olarak iyi düzeyde uyum gösterdiği ve dört faktörlü yapısının doğrulandığı anlaşılmıştır. DFA sonucunda sosyal, işlevsel, hedonik ve bilişsel yenilikçilik faktörlerinde bulunan maddelerin faktör yükleri sırasıyla 0,67-0,83; 0,53-0,88; 0,82-0,91 ve 0,63-0,91 arasında değişen değerler almıştır. Modelde gösterilen tüm yol katsayıları $p<0,001$ düzeyinde istatistiksel olarak anlamlıdır.

Güdülenmiş Tüketici Yenilikçiliği Ölçeği'nin iç tutarlılık ile ilişkili güvenirlik düzeyini incelemek için Cronbach Alfa katsayısı kullanılmıştır. Alfa katsayısının 0,70 ve daha yüksek bulunması ölçeğin güvenirliğinin yeterli düzeyde olduğunu göstermektedir (Tavşancıl, 2005). Sosyal, işlevsel, hedonik ve bilişsel yenilikçilik faktörleri için hesaplanan Cronbach alfa katsayıları sırası ile 0,88; 0,86; 0,94 ve 0,92' dir. Bu değerler ölçeğin iç tutarlılığa bağlı güvenirliğinin yüksek düzeyde olduğunu göstermiştir. Doğrulayıcı faktör analizi sonuçları, ölçeğin orijinal yapısını koruduğunu göstermiştir. Katılımcılardan elde edilen verilerin ölçeğin yapısı ile uyumlu olduğu anlaşılmıştır. Güvenirlik analizi sonuçları ise ölçek faktörlerine ait puanların güvenirliğinin yeterli düzede olduğunu işaret etmiştir.

Sosyal Onay İhtiyacı Ölçeği'nin doğrulayıcı faktör analizi ile hesaplanan, standardize edilmiş tahmin sonuçlarına göre, modelin istatistiksel olarak anlamlı olduğu ve modele ait değerlerin uyum kriterlerini karşıladığı anlaşılmıştır. Ölçeğin üç faktörlü yapısının eldeki veriler ile genel olarak iyi düzeyde uyum gösterdiği ve üç faktörlü yapısının doğrulandığı anlaşılmıştır. DFA sonucunda başkalarının duygularına duyarlılık, sosyal geri çekilme ve olumlu izlenim bırakma faktörlerinde bulunan maddelerin faktör yükleri sırasıyla 0,67-0,85; 0,63-0,82 ve 0,71-0,89 arasında değişen değerler almıştır. Modelde gösterilen tüm yol katsayıları $p<0,001$ düzeyinde istatistiksel olarak anlamlı bulunmuştur. 


\section{A. T. Özden 11/3 (2019) 1537-1558}

Sosyal Onay İhtiyacı Ölçeği'nin iç tutarlılık ile ilişkili güvenirlik düzeyini incelemek için Cronbach Alfa katsayısı kullanılmıştır. Alfa katsayısının 0,70 ve daha yüksek bulunması ölçeğin güvenirliğinin yeterli düzeyde olduğunu göstermektedir (Tavşancıl, 2005). Başkalarının duygularına duyarlılık, sosyal geri çekilme ve olumlu izlenim bırakma faktörleri için hesaplanan Cronbach alfa katsayıları sırası ile 0,94; 0,91 ve 0,94'dür. Bu değerler ölçeğin iç tutarlılığa bağlı güvenirliğinin yüksek düzeyde olduğunu göstermiştir. Doğrulayıcı faktör analizi sonuçları, ölçeğin orijinal yapısını koruduğunu göstermiştir. Eldeki verilerin ölçeğin yapısı ile uyumlu olduğu anlaşılmıştır. Güvenirlik analizi sonuçları ise ölçek faktörlerine ait puanların güvenirliğinin yeterli düzede olduğunu işaret etmiştir.

\subsection{Verilerin İstatistiksel Analizi}

Araştırmanın amacı doğrultusunda Güdülenmiş Tüketici Yenilikçiliği ve Sosyal Onay İhtiyacı ölçeklerinden alınan puanları; kuşak, cinsiyet, gelir düzeyi ve eğitim durumu değişkenlerine göre karşılaştırmak için parametrik analizler uygulanmıştır.

Parametrik analiz teknikleri uygulanmadan önce karşılanması gereken varsayımlar kontrol edilmiştir. Bu doğrultuda öncelikle veri setinde normal dağılımı güçleştiren uç değerlerin olup olmadığı araştırılmıştır. Kutu grafikleri oluşturularak bu durum incelenmiştir. Elde edilen grafikler veri setinde uç değerlerin bulunmadığını göstermiştir. Bir sonraki adımda kullanılan ölçeklerden elde edilen puanlara ait çarpıklık ve basıklık değerleri hesaplanarak normal dağılım varsayımı kontrol edilmiştir. Bu değerlerin \pm 2 aralığında bulunması normal dağılım için yeterli görülmektedir (George ve Mallery, 2010). Hesaplanan değerlerin belirtilen aralıkta yer aldığı, normal dağılım varsayımının karşılandığı anlaşılmıştır (Tablo 1).

Tablo 1. Ölçeklerden Elde Edilen Puanlara Ait Betimsel Bilgiler

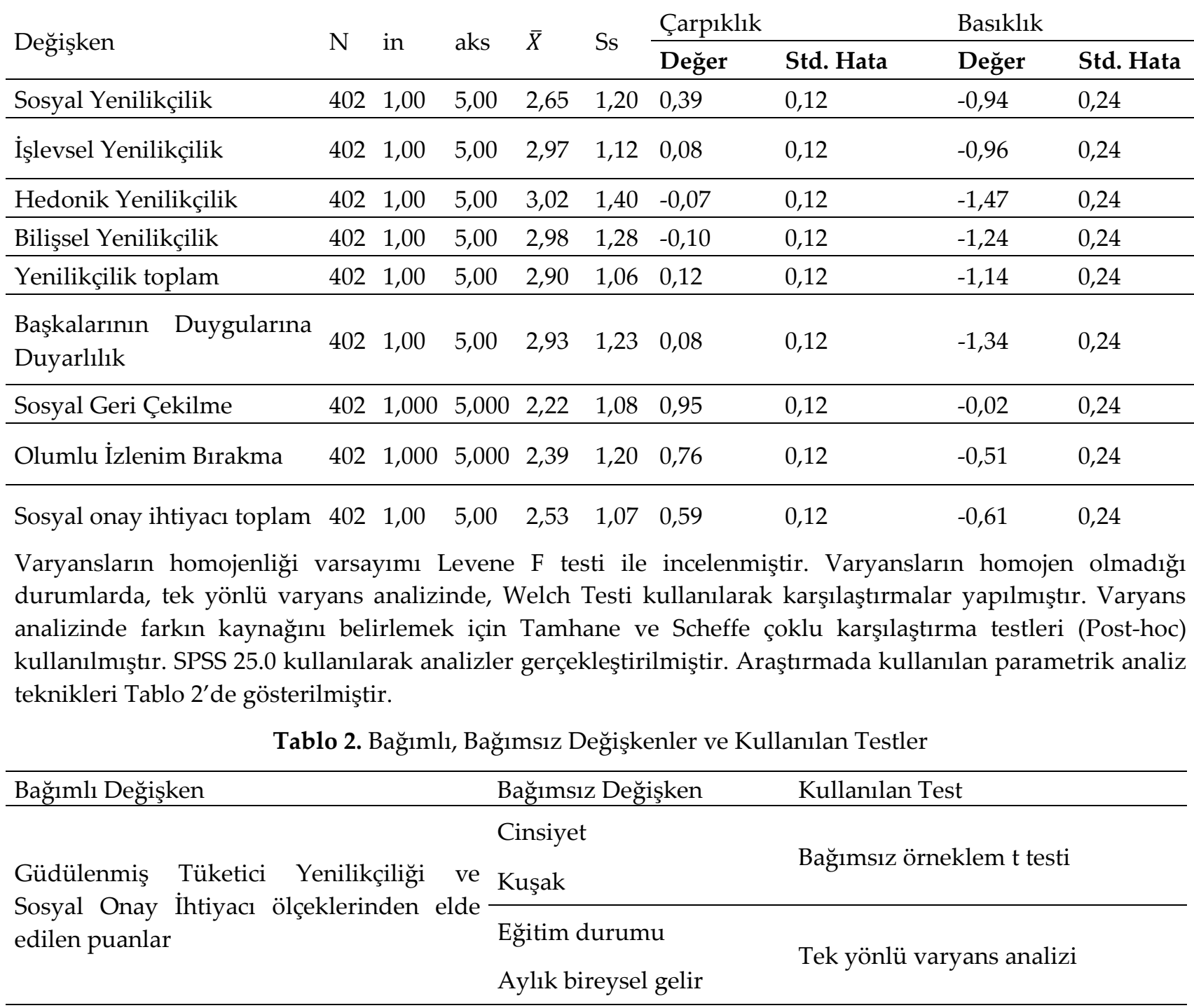




\section{A. T. Özden 11/3 (2019) 1537-1558}

Araştırmanın amacı doğrultusunda, Güdülenmiş Tüketici Yenilikçiliği ve Sosyal Onay İhtiyacı ölçeklerinden elde edilen puanlar arasındaki ilişkileri incelemek için Pearson Korelasyon analizi uygulanmıştır. Analiz sonucunda elde edilen 0 ile $\pm 0,30$ arasındaki katsayılar düşük, $\pm 0,31$ ile $\pm 0,70$ arasındaki katsayılar orta ve $\pm 0,71$ ile \pm 1 arasındaki katsayılar ise yüksek ilişkileri göstermektedir (Büyüköztürk, 2006).

Araştırma kapsamında, sosyal onay ihtiyacının tüketici yenilikçiliği üzerindeki etkisini belirlemek için doğrusal regresyon analizleri gerçekleştirilmiştir. Regresyon analizine dâhil edilen değişkenler arasında çoklu bağlantının olup olmadığını belirlemek için VIF (Variance Inflation Factor) değerleri hesaplanmış ve incelenmiştir. VIF değerinin 10 ve daha yüksek olması veriler arasında çoklu bağlantının olduğunu göstermektedir (Çokluk, vd., 2012). Bu araştırmada elde edilen VIF değerleri $(2,20<\mathrm{VIF}<5,09)$ değişkenler arasında çoklu bağlantının olmadığını göstermiştir. Değişkenler arasındaki ilişkilerin doğrusal olup olmadığını belirlemek için ise saçılma diyagramı matrisi oluşturulmuş ve incelenmiştir. Diyagramda gözlenen ikili ilişkilerin her birinin doğrusal olduğu belirlenmiştir. Sonuç olarak, verilerin regresyon analizine uygun olduğu anlaşılmıştır.

\subsection{Bulgular}

Güdülenmiş Tüketici Yenilikçiliği ve Sosyal Onay İhtiyacı ölçeklerinden elde edilen puanlar arasındaki ilişkilere ait Pearson Korelasyon Katsayıları Tablo 3'deki gibidir.

Tablo 3. Güdülenmiş Tüketici Yenilikçiliği ve Sosyal Onay İhtiyacı Ölçeklerinden Elde Edilen Puanlar Arasındaki İlişkilere Ait Pearson Korelasyon Katsayıları

\begin{tabular}{|c|c|c|c|c|c|c|c|c|c|}
\hline Değişkenler & $\bar{X}$ & Ss & 1. & 2. & 3. & 4. & 5. & 6. & 7. \\
\hline 1. Sosyal Yenilikçilik & 2,65 & 1,20 & 1 & & & & & & \\
\hline İşlevsel Yenilikçilik & 2,97 & 1,12 & , $611^{* *}$ & 1 & & & & & \\
\hline 3. Hedonik Yenilikçilik & 3,02 & 1,40 &, $665^{* *}$ &, $595^{* *}$ & 1 & & & & \\
\hline 4. Bilişsel Yenilikçilik & 2,98 & 1,28 &, $549^{* *}$ & $688^{* * *}$ & $632^{* *}$ & 1 & & & \\
\hline $\begin{array}{l}\text { 5. } \begin{array}{l}\text { Başkalarının Duygularına } \\
\text { Duyarlılık }\end{array} \\
\end{array}$ & 2,93 & 1,23 & ,680** &, $635^{* *}$ &, $786^{* *}$ & $662^{* *}$ & 1 & & \\
\hline 6. Sosyal Geri Çekilme & 2,22 & 1,08 &, $590^{* *}$ & $498^{* *}$ & $454^{* *}$ & $422^{* *}$ & $660^{* *}$ & 1 & \\
\hline 7. Olumlu İzlenim Bırakma & 2,39 & 1,20 & ,632 & $492^{* *}$ &, $574^{* *}$ & $475^{* *}$ &, $737^{* *}$ & $870^{* *}$ & 1 \\
\hline
\end{tabular}

Tablo incelendiğinde, başkalarının duygularına duyarlılık puanları ile sosyal yenilikçilik $(\mathrm{r}=0,680 ; \mathrm{p}<0,01)$, işlevsel yenilikçilik $(r=0,635 ; \mathrm{p}<0,01)$, hedonik yenilikçilik $(\mathrm{r}=0,786 ; \mathrm{p}<0,01)$ ve bilişsel yenilikçilik $(\mathrm{r}=0,662$; $\mathrm{p}<0,01)$ puanları arasında orta ve yüksek düzeyde pozitif yönlü anlamlı ilişkilerin bulunduğu anlaşılmaktadır.

Sosyal geri çekilme puanları ile sosyal yenilikçilik $(r=0,590 ; p<0,01)$, işlevsel yenilikçilik $(r=0,498 ; p<0,01)$, hedonik yenilikçilik $(r=0,454 ; \mathrm{p}<0,01)$ ve bilişsel yenilikçilik $(\mathrm{r}=0,422 ; \mathrm{p}<0,01)$ puanları arasında orta düzeyde pozitif yönlü anlamlı ilişkilerin bulunduğu anlaşılmaktadır.

Olumlu izlenim bırakma puanları ile sosyal yenilikçilik $(r=0,632 ; p<0,01)$, işlevsel yenilikçilik $(r=0,492$; $\mathrm{p}<0,01)$, hedonik yenilikçilik $(\mathrm{r}=0,474 ; \mathrm{p}<0,01)$ ve bilişsel yenilikçilik $(\mathrm{r}=0,475 ; \mathrm{p}<0,01)$ puanları arasında orta düzeyde pozitif yönlü anlamlı ilişkilerin bulunduğu anlaşılmaktadır.

$\mathrm{Bu}$ doğrultuda $\mathrm{H} 1$ hipotezi (Sosyal onay ihtiyacı ve tüketici yenilikçiliği arasında anlamlı bir ilişki bulunmaktadır.) desteklenmiştir.

Sosyal onay ihtiyacının işlevsel yenilikçilik üzerindeki etkisini belirlemek için uygulanan regresyon analizi sonuçları Tablo 4'de sunulmuştur. 


\section{A. T. Özden 11/3 (2019) 1537-1558}

Tablo 4. Sosyal Onay İhtiyacının İşlevsel Yenilikçilik Üzerindeki Etkisini Belirlemek İçin Uygulanan Regresyon Analizi Sonuçları

\begin{tabular}{llllll}
\hline Değişken & $\mathrm{B}$ & $\begin{array}{l}\text { Standart } \\
\text { Hata }\end{array}$ & $\beta$ & $\mathrm{t}$ & $\mathrm{p}$ \\
\hline Sabit & 1,19 & 0,11 & & 10,42 & 0,00 \\
\hline Başkalarının Duygularına Duyarlılık & 0,53 & 0,05 & 0,59 & 10,34 & 0,00 \\
\hline Sosyal Geri Çekilme & 0,25 & 0,08 & 0,24 & 3,11 & 0,00 \\
\hline Olumlu İzlenim Bırakma & $-0,14$ & 0,08 & $-0,15$ & $-1,73$ & 0,08 \\
\hline $\mathrm{R}=0,647$ & $\mathrm{R}^{2}=0,418$ & & $\mathrm{~F}=95,47$ & & $p<0,001$ \\
\hline
\end{tabular}

Bağımlı Değişken: İşlevsel yenilikçilik

Tablo 4 incelendiğinde, sosyal onay ihtiyacı bileşenlerinin işlevsel yenilikçilik üzerindeki etkisini test etmek için geliştirilen regresyon modeli istatistiksel olarak anlamlı bulunmuştur $R=0,647 ; R^{2}=0,418 ; p<0,001$. Sosyal onay ihtiyacı bileşenleri işlevsel yenilikçilikteki toplam varyansın \%42'sini açıklamaktadır. Yol katsayılarına ait anlamlılık değerleri incelendiğinde, sosyal onay ihtiyacı bileşenlerinden sadece başkalarının duygularına duyarlılık $(\beta=0,59 ; p<0,01)$ ve sosyal geri çekilme $(\beta=0,24 ; p<0,01)$ bileşenlerinin işlevsel yenilikçiliğin anlamlı yordayıcıları olduğu anlaşılmaktadır. Katılımcıların başkalarının duygularına duyarlılık ve sosyal geri çekilme algısı arttıkça işlevsel yenilikçilik algıları da artış göstermektedir. Bu doğrultuda H1a (Başkalarının yargılarına duyarlılık, işlevsel yenilikçilik üzerinde etkilidir.) ve H1b (Sosyal geri çekilme, işlevsel yenilikçilik üzerinde etkilidir.) hipotezleri desteklenmiştir. H1c (Olumlu izlenim bırakma, işlevsel yenilikçilik üzerinde etkilidir.) hipotezi desteklenmemiştir.

Sosyal onay ihtiyacının hedonik yenilikçilik üzerindeki etkisini belirlemek için uygulanan regresyon analizi sonuçları Tablo 5'de sunulmuştur.

Tablo 5. Sosyal Onay İhtiyacının Hedonik Yenilikçilik Üzerindeki Etkisini Belirlemek İçin Uygulanan Regresyon Analizi Sonuçları

\begin{tabular}{llllll}
\hline Değişken & $\mathrm{B}$ & $\begin{array}{l}\text { Standart } \\
\text { Hata }\end{array}$ & $\beta$ & $\mathrm{t}$ & $\mathrm{p}$ \\
\hline Sabit & 0,50 & 0,11 & & 4,46 & 0,00 \\
\hline Başkalarının Duygularına Duyarlılık & 0,92 & 0,05 & 0,80 & 17,90 & 0,00 \\
\hline Sosyal Geri Çekilme & $-0,32$ & 0,08 & $-0,25$ & $-4,08$ & 0,00 \\
\hline Olumlu İzlenim Bırakma & 0,23 & 0,08 & 0,20 & 2,92 & 0,00 \\
\hline $\mathrm{R}=0,796$ & $\mathrm{R}^{2}=0,633$ & $\mathrm{~F}=229,22$ & & $p<0,001$ \\
\hline
\end{tabular}

Bağımlı Değişken: Hedonik yenilikçilik

Tablo incelendiğinde, sosyal onay ihtiyacı bileşenlerinin hedonik yenilikçilik üzerindeki etkisini test etmek için geliştirilen regresyon modeli istatistiksel olarak anlamlı bulunmuştur $R=0,796 ; R^{2}=0,633 ; p<0,001$. Sosyal onay ihtiyacı bileşenleri hedonik yenilikçilikteki toplam varyansın \%63'ünü açıklamaktadır. Yol katsayılarına ait anlamlılık değerleri incelendiğinde, başkalarının duygularına duyarlılık $(\beta=0,80 ; p<0,01)$, sosyal geri çekilme $(\beta=-0,25 ; p<0,01)$ ve olumlu izlenim bırakma $(\beta=0,20 ; p<0,01)$ bileşenlerinin hedonik yenilikçiliğin anlamlı yordayıcıları olduğu anlaşılmaktadır. Katılımcıların başkalarının duygularına duyarlılık ve olumlu izlenim bırakma algıları arttıkça hedonik yenilikçilik algıları artmakta, sosyal geri çekilme algıları arttıkça hedonik yenilikçilik algıları azalmaktadır. Bu doğrultuda H1d (Başkalarının yargılarına duyarlılık, hedonik yenilikçilik üzerinde etkilidir.), H1e (Sosyal geri çekilme, hedonik yenilikçilik üzerinde etkilidir.), H1f (Olumlu izlenim bırakma, hedonik yenilikçilik üzerinde etkilidir.) hipotezleri desteklenmiştir.

Sosyal onay ihtiyacının sosyal yenilikçilik üzerindeki etkisini belirlemek için uygulanan regresyon analizi sonuçları Tablo 6'da sunulmuştur. 


\section{A. T. Özden 11/3 (2019) 1537-1558}

Tablo 6. Sosyal Onay İhtiyacının Sosyal Yenilikçilik Üzerindeki Etkisini Belirlemek İçin Uygulanan Regresyon Analizi Sonuçları

\begin{tabular}{llllll}
\hline Değişken & $\mathrm{B}$ & $\begin{array}{l}\text { Standart } \\
\text { Hata }\end{array}$ & $\beta$ & $\mathrm{t}$ & $\mathrm{p}$ \\
\hline Sabit & 0,58 & 0,11 & & 5,10 & 0,00 \\
\hline Başkalarının Duygularına Duyarlılık & 0,45 & 0,05 & 0,46 & 8,87 & 0,00 \\
\hline Sosyal Geri Çekilme & 0,14 & 0,08 & 0,13 & 1,82 & 0,07 \\
\hline Olumlu İzlenim Birakma & 0,18 & 0,08 & 0,18 & 2,22 & 0,03 \\
\hline $\mathrm{R}=0,710$ & $\mathrm{R}^{2}=0,504$ & & $\mathrm{~F}=134,84$ & & $p<0,001$ \\
\hline
\end{tabular}

Bağımlı Değişken: Sosyal yenilikçilik

Tablo incelendiğinde, sosyal onay ihtiyacı bileşenlerinin sosyal yenilikçilik üzerindeki etkisini test etmek için geliştirilen regresyon modeli istatistiksel olarak anlamlı bulunmuştur $R=0,710 ; R^{2}=0,504 ; p<0,001$. Sosyal onay ihtiyacı bileşenleri sosyal yenilikçilikteki toplam varyansın \%50'sini açıklamaktadır. Yol katsayılarına ait anlamlılık değerleri incelendiğinde, sadece başkalarının duygularına duyarlılık $(\beta=0,46 ; p<0,01)$ ve olumlu izlenim bırakma $(\beta=0,18 ; \quad p<0,05)$ bileşenlerinin sosyal yenilikçiliğin anlamlı yordayıcıları olduğu anlaşılmaktadır. Katılımcıların başkalarının duygularına duyarlılık ve olumlu izlenim bırakma algısı arttıkça tüketici yenilikçiliği ile ilgili sosyal yenilikçilik algıları da artış göstermektedir. Bu doğrultuda H1g (Başkalarının yargılarına duyarlılık, sosyal yenilikçilik üzerinde etkilidir.) ve H1ı (Olumlu izlenim bırakma, sosyal yenilikçilik üzerinde etkilidir.) hipotezleri desteklenmiş; H1h (Sosyal geri çekilme, sosyal yenilikçilik üzerinde etkilidir.) hipotezi desteklenmemiştir.

Sosyal onay ihtiyacının sosyal yenilikçilik üzerindeki etkisini belirlemek için uygulanan regresyon analizi sonuçları Tablo 7'de sunulmuştur.

Tablo 7. Sosyal Onay İhtiyacının Sosyal Yenilikçilik Üzerindeki Etkisini Belirlemek İçin Uygulanan Regresyon Analizi Sonuçları

\begin{tabular}{llllll}
\hline Değişken & $\mathrm{B}$ & $\begin{array}{l}\text { Standart } \\
\text { Hata }\end{array}$ & $\beta$ & $\mathrm{t}$ & $\mathrm{p}$ \\
\hline Sabit & 0,97 & 0,13 & & 7,57 & 0,00 \\
\hline Başkalarının Duygularına Duyarlılık & 0,71 & 0,06 & 0,68 & 12,29 & 0,00 \\
\hline Sosyal Geri Çekilme & $-0,02$ & 0,09 & $-0,02$ & $-0,23$ & 0,82 \\
\hline Olumlu İzlenim Birakma & $-0,01$ & 0,09 & $-0,01$ & $-0,16$ & 0,87 \\
\hline $\mathrm{R}=0,663$ & $\mathrm{R}^{2}=0,439$ & & $\mathrm{~F}=103,85$ & & $p<0,001$ \\
\hline
\end{tabular}

Bağımlı Değişken: Bilişsel yenilikçilik

Tablo incelendiğinde, sosyal onay ihtiyacı bileşenlerinin bilişsel yenilikçilik üzerindeki etkisini test etmek için geliştirilen regresyon modeli istatistiksel olarak anlamlı bulunmuştur $\mathrm{R}=0,663 ; \mathrm{R}^{2}=0,439 ; p<0,001$. Sosyal onay ihtiyacı bileşenleri bilişsel yenilikçilikteki toplam varyansın \%44'ünü açıklamaktadır. Yol katsayılarına ait anlamlılık değerleri incelendiğinde, sadece başkalarının duygularına duyarlılık bileşeninin bilişsel yenilikçiliğin anlamlı yordayıcısı olduğu anlaşılmaktadır $(\beta=0,68 ; p<0,01)$. Katılımcıların başkalarının duygularına yönelik duyarlılık algısı arttıkça bilişsel yenilikçilik algıları da artış göstermektedir. Bu doğrultuda, H1i (Başkalarının yargılarına duyarlılık, bilişsel yenilikçilik üzerinde etkilidir.) hipotezi desteklenmiştir. H1j (Sosyal geri çekilme, bilişsel yenilikçilik üzerinde etkilidir.) ve H1k (Olumlu izlenim bırakma, bilişsel yenilikçilik üzerinde etkilidir.) hipotezleri desteklenmemiştir.

Güdülenmiş Tüketici Yenilikçiliği Ölçeği puanlarının Y ve Z kuşaklarına göre karşılaştırılması Tablo 8’ de sunulmuştur. 


\section{A. T. Özden 11/3 (2019) 1537-1558}

Tablo 8. Güdülenmiş Tüketici Yenilikçiliği Ölçeği Puanlarının Y ve Z Kuşaklarına Göre Karşılaştııılması

\begin{tabular}{|c|c|c|c|c|c|c|c|}
\hline Değişken & Kuşak & $\mathrm{N}$ & $\bar{X}$ & Ss & $\mathrm{t}$ & $\mathrm{p}$ & Cohen d \\
\hline \multirow{2}{*}{ Sosyal Yenilikçilik } & Z Kuşağ1 & 187 & 3,23 & 1,09 & \multirow{2}{*}{10,15} & \multirow{2}{*}{0,00} & \multirow{2}{*}{1,02} \\
\hline & Y Kuşağ1 & 215 & 2,14 & 1,06 & & & \\
\hline \multirow{2}{*}{ İşlevsel Yenilikçilik } & Z Kuşağ1 & 187 & 3,52 & 0,97 & \multirow{2}{*}{10,38} & \multirow{2}{*}{0,00} & \multirow{2}{*}{1,04} \\
\hline & Y Kuşağ1 & 215 & 2,49 & 1,02 & & & \\
\hline \multirow{2}{*}{ Hedonik Yenilikçilik } & Z Kuşağ1 & 187 & 3,96 & 0,97 & \multirow{2}{*}{16,20} & \multirow{2}{*}{0,00} & \multirow{2}{*}{1,62} \\
\hline & Y Kuşağ1 & 215 & 2,20 & 1,18 & & & \\
\hline \multirow{2}{*}{ Bilişsel Yenilikçilik } & Z Kuşağ1 & 187 & 3,77 & 0,88 & \multirow{2}{*}{$-14,21$} & \multirow{2}{*}{0,00} & \multirow{2}{*}{1,42} \\
\hline & Y Kuşağ1 & 215 & 2,29 & 1,17 & & & \\
\hline \multirow{2}{*}{ Tüketici Yenilikçiliği toplam } & Z Kuşağ1 & 187 & 3,62 & 0,76 & \multirow{2}{*}{$-16,34$} & \multirow{2}{*}{0,00} & \multirow{2}{*}{1,63} \\
\hline & Y Kuşağ1 & 215 & 2,28 & 0,87 & & & \\
\hline
\end{tabular}

Tablo incelendiğinde, sosyal, işlevsel, hedonik, bilişsel yenilikçilik ve genel tüketici yenilikçiliği toplam puan ortalamalarında $Y$ ve $Z$ kuşaklarına bağlı anlamlı bir farklılık gözlenmiştir $(p<0,05)$. $Z$ kuşağında yer alan katılımcıların; sosyal, işlevsel, hedonik, bilişsel yenilikçilik ve genel tüketici yenilikçiliği puan ortalamaları anlamlı olarak daha yüksek bulunmuştur.

Bu doğrultuda H2a (Y ve Z kuşağı tüketicilerinin yenilikçilik düzeyleri anlamlı bir farklılık göstermektedir.) hipotezi desteklenmiştir.

Güdülenmiş Tüketici Yenilikçiliği Ölçeği puanlarının cinsiyete göre karşılaştırılması Tablo 9'da sunulmuştur.

Tablo 9. Güdülenmiş Tüketici Yenilikçiliği Ölçeği Puanlarının Cinsiyete Göre Karşılaştııılması

\begin{tabular}{|c|c|c|c|c|c|c|c|}
\hline Değişken & Cinsiyet & $\mathrm{N}$ & $\bar{X}$ & Ss & $\mathrm{t}$ & $\mathrm{p}$ & Cohen d \\
\hline \multirow{2}{*}{ Sosyal Yenilikçilik } & Kadın & 189 & 2,72 & 1,16 & \multirow{2}{*}{1,14} & \multirow{2}{*}{0,26} & \multirow{2}{*}{0,11} \\
\hline & Erkek & 213 & 2,58 & 1,24 & & & \\
\hline \multirow{2}{*}{ İşlevsel Yenilikçilik } & Kadın & 189 & 2,98 & 1,09 & \multirow{2}{*}{0,16} & \multirow{2}{*}{0,88} & \multirow{2}{*}{0,02} \\
\hline & Erkek & 213 & 2,96 & 1,15 & & & \\
\hline \multirow{2}{*}{ Hedonik Yenilikçilik } & Kadın & 189 & 3,32 & 1,34 & \multirow{2}{*}{4,15} & \multirow{2}{*}{0,00} & \multirow{2}{*}{0,42} \\
\hline & Erkek & 213 & 2,75 & 1,39 & & & \\
\hline \multirow{2}{*}{ Bilişsel Yenilikçilik } & Kadın & 189 & 3,00 & 1,28 & \multirow{2}{*}{0,34} & \multirow{2}{*}{0,73} & \multirow{2}{*}{0,03} \\
\hline & Erkek & 213 & 2,96 & 1,28 & & & \\
\hline \multirow{2}{*}{ Yenilikçilik toplam } & Kadın & 189 & 3,01 & 1,05 & \multirow{2}{*}{1,82} & \multirow{2}{*}{0,07} & \multirow{2}{*}{0,18} \\
\hline & Erkek & 213 & 2,81 & 1,06 & & & \\
\hline
\end{tabular}

Tablo incelendiğinde, sosyal, işlevsel, bilişsel yenilikçilik ve genel tüketici yenilikçiliği toplam puan ortalamalarında cinsiyete bağlı anlamlı bir farklılık gözlenmemiştir $(\mathrm{p}>0,05)$. Bununla birlikte, katılımcıların hedonik yenilikçilik puan ortalamalarında cinsiyete bağlı anlamlı bir farklılık gözlenmiştir $(p<0,05)$. Kadınların hedonik yenilikçilik puan ortalamaları anlamlı olarak daha yüksek bulunmuştur.

$\mathrm{Bu}$ doğrultuda $\mathrm{H} 2 \mathrm{~b}$ (Tüketici yenilikçiliği cinsiyete göre anlamlı bir farklılık göstermektedir.) desteklenmemiştir.

Güdülenmiş Tüketici Yenilikçiliği Ölçeği puanlarının eğitim durumuna göre karşılaştırılması Tablo 10'da sunulmuştur. 


\section{A. T. Özden 11/3 (2019) 1537-1558}

Tablo 10. Güdülenmiş Tüketici Yenilikçiliği Ölçeği Puanlarının Eğitim Durumuna Göre Karşılaştırılması

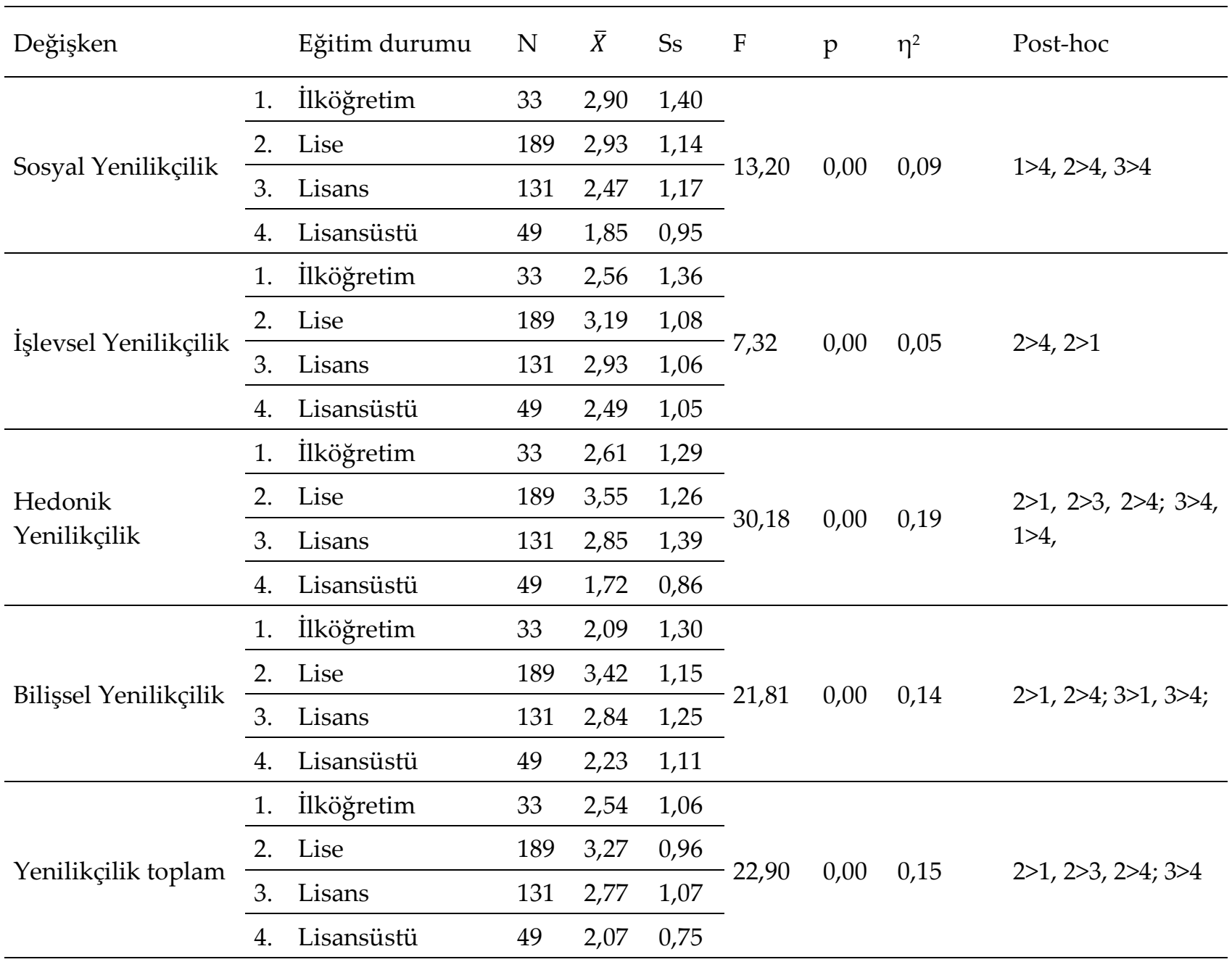

Tablo incelendiğinde, sosyal, işlevsel, hedonik, bilişsel yenilikçilik ve genel tüketici yenilikçiliği toplam puan ortalamalarında eğitim durumuna bağlı anlamlı bir farklılık gözlenmiştir $(\mathrm{p}<0,05)$. Genel olarak, lisansüstü mezunu katılımcıların; sosyal, işlevsel, hedonik, bilişsel yenilikçilik ve genel tüketici yenilikçiliği toplam puan ortalamaları en düşük, lise mezunu katılımcıların; sosyal, işlevsel, hedonik, bilişsel yenilikçilik ve genel tüketici yenilikçiliği toplam puan ortalamaları ise en yüksek bulunmuştur.

$\mathrm{Bu}$ doğrultuda $\mathrm{H} 2 \mathrm{c}$ (Tüketici yenilikçiliği eğitim seviyesine göre anlamlı bir farklılık göstermektedir.) hipotezi desteklenmiştir.

Güdülenmiş Tüketici Yenilikçiliği Ölçeği puanlarının aylık bireysel gelire göre karşılaştırılması Tablo 11'de sunulmuştur.

Tablo 11. Güdülenmiş Tüketici Yenilikçiliği Ölçeği Puanlarının Aylık Bireysel Gelire Göre Karşılaştırılması

\begin{tabular}{|c|c|c|c|c|c|c|c|c|c|}
\hline Değişken & & bireysel & $\mathbf{N}$ & $\bar{X}$ & Ss & $\mathbf{F}$ & $\mathbf{p}$ & $\eta^{2}$ & Post-hoc \\
\hline \multirow{5}{*}{$\begin{array}{l}\text { Sosyal } \\
\text { Yenilikçilik }\end{array}$} & 1. & 2000 TL'den az & 149 & 3,00 & 1,10 & \multirow{5}{*}{7,48} & \multirow{5}{*}{0,00} & \multirow{5}{*}{0,07} & \multirow{5}{*}{$1>4,1>5$} \\
\hline & 2. & 2001-5000 TL & 116 & 2,55 & 1,19 & & & & \\
\hline & 3. & 5001-8000 TL & 81 & 2,54 & 1,22 & & & & \\
\hline & 4. & $8001-11000 \mathrm{TL}$ & 33 & 1,99 & 1,05 & & & & \\
\hline & 5. & 11000 TL üzeri & 23 & 2,15 & 1,32 & & & & \\
\hline \multirow{2}{*}{$\begin{array}{l}\text { İşlevsel } \\
\text { Yenilikçilik }\end{array}$} & 1. & 2000 TL'den az & 149 & 3,12 & 1,12 & \multirow{2}{*}{3,07} & \multirow{2}{*}{0,02} & \multirow{2}{*}{0,03} & \multirow{2}{*}{$1>4,1>5$} \\
\hline & 2. & 2001-5000 TL & 116 & 3,00 & 1,10 & & & & \\
\hline
\end{tabular}


A. T. Özden 11/3 (2019) 1537-1558

\begin{tabular}{|c|c|c|c|c|c|c|c|c|}
\hline & 3. $5001-8000 \mathrm{TL}$ & 81 & 2,96 & 1,07 & & & & \\
\hline & 4. $8001-11000 \mathrm{TL}$ & 33 & 2,55 & 1,01 & & & & \\
\hline & 5. 11000 TL üzeri & 23 & 2,48 & 1,31 & & & & \\
\hline \multirow{5}{*}{$\begin{array}{l}\text { Hedonik } \\
\text { Yenilikçilik }\end{array}$} & 1. 2000 TL'den az & 149 & 3,57 & 1,21 & \multirow{5}{*}{16,43} & \multirow{5}{*}{0,00} & \multirow{5}{*}{0,14} & \multirow{5}{*}{$1>4,1>5$} \\
\hline & 2. $2001-5000 \mathrm{TL}$ & 116 & 2,90 & 1,36 & & & & \\
\hline & 3. $5001-8000 \mathrm{TL}$ & 81 & 2,92 & 1,43 & & & & \\
\hline & 4. $8001-11000 \mathrm{TL}$ & 33 & 1,82 & 1,06 & & & & \\
\hline & 5. 11000 TL üzeri & 23 & 2,19 & 1,43 & & & & \\
\hline \multirow{5}{*}{$\begin{array}{l}\text { Bilişsel } \\
\text { Yenilikçilik }\end{array}$} & 1. 2000 TL'den az & 149 & 3,19 & 1,25 & \multirow{5}{*}{4,40} & \multirow{5}{*}{0,00} & \multirow{5}{*}{0,04} & \multirow{5}{*}{$1>4,1>5$} \\
\hline & 2. $2001-5000 \mathrm{TL}$ & 116 & 3,07 & 1,33 & & & & \\
\hline & 3. $5001-8000 \mathrm{TL}$ & 81 & 2,83 & 1,21 & & & & \\
\hline & 4. $8001-11000 \mathrm{TL}$ & 33 & 2,32 & 1,05 & & & & \\
\hline & 5. 11000 TL üzeri & 23 & 2,57 & 1,38 & & & & \\
\hline \multirow{5}{*}{$\begin{array}{l}\text { Yenilikçilik } \\
\text { toplam }\end{array}$} & 1. 2000 TL'den az & 149 & 3,22 & 0,96 & \multirow{5}{*}{9,90} & \multirow{5}{*}{0,00} & \multirow{5}{*}{0,09} & \multirow{5}{*}{$1>4,1>5 ; 2>4 ; 3>4$} \\
\hline & 2. $2001-5000 \mathrm{TL}$ & 116 & 2,88 & 1,06 & & & & \\
\hline & 3. $5001-8000 \mathrm{TL}$ & 81 & 2,81 & 1,08 & & & & \\
\hline & 4. $8001-11000 \mathrm{TL}$ & 33 & 2,17 & 0,75 & & & & \\
\hline & 5. 11000 TL üzeri & 23 & 2,35 & 1,25 & & & & \\
\hline
\end{tabular}

Tablo incelendiğinde, sosyal, işlevsel, hedonik, bilişsel yenilikçilik ve genel tüketici yenilikçiliği toplam puan ortalamalarında aylık bireysel gelire bağlı anlamlı bir farklılık gözlenmiştir $(p<0,05)$. Genel olarak, aylık bireysel gelirinin "2000 TL'den az" olduğunu belirten katılımcıların; sosyal, işlevsel, hedonik, bilişsel yenilikçilik ve genel tüketici yenilikçiliği toplam puan ortalamaları en yüksek, aylık bireysel gelirinin "8001 11000 TL" ve "11000 TL üzeri" olduğunu belirten katılımcıların; sosyal, işlevsel, hedonik, bilişsel yenilikçilik ve genel tüketici yenilikçiliği toplam puan ortalamaları ise en düşük bulunmuştur.

Bu doğrultuda H2d (Tüketici yenilikçiliği gelir durumuna göre anlamlı bir farklılık göstermektedir.) hipotezi desteklenmiştir.

Sosyal Onay İhtiyacı Ölçeği Puanlarının Y ve Z kuşaklarına göre karşılaştırılması Tablo 12' de sunulmuştur.

Tablo 12. Sosyal Onay İhtiyacı Ölçeği Puanlarının Y ve Z Kuşaklarına Göre Karşılaştııılması

\begin{tabular}{|c|c|c|c|c|c|c|c|}
\hline Değişken & Kuşak & $\mathrm{N}$ & $\bar{X}$ & Ss & $\mathrm{t}$ & $\mathrm{p}$ & Cohen $\mathrm{d}$ \\
\hline \multirow{2}{*}{ Başkalarının Duygularına Duyarlılık } & Z Kuşağ1 & 187 & 3,76 & 0,89 & \multirow{2}{*}{16,33} & \multirow{2}{*}{0,00} & \multirow{2}{*}{1,63} \\
\hline & Y Kuşağ1 & 215 & 2,20 & 1,01 & & & \\
\hline \multirow{2}{*}{ Sosyal Geri Çekilme } & Z Kuşağ 1 & 187 & 2,70 & 1,20 & \multirow{2}{*}{9,12} & \multirow{2}{*}{0,00} & \multirow{2}{*}{0,91} \\
\hline & Y Kuşağ1 & 215 & 1,80 & 0,75 & & & \\
\hline \multirow{2}{*}{ Olumlu İzlenim Bırakma } & Z Kuşağ 1 & 187 & 3,06 & 1,23 & \multirow{2}{*}{12,29} & \multirow{2}{*}{0,00} & \multirow{2}{*}{1,23} \\
\hline & Y Kuşağ1 & 215 & 1,81 & 0,80 & & & \\
\hline \multirow{2}{*}{ Sosyal onay ihtiyacı toplam } & Z Kuşağ1 & 187 & 3,20 & 0,99 & \multirow{2}{*}{14,35} & \multirow{2}{*}{0,00} & \multirow{2}{*}{1,44} \\
\hline & Y Kuşağ 1 & 215 & 1,95 & 0,76 & & & \\
\hline
\end{tabular}

Tablo incelendiğinde, başkalarının duygularına duyarlılık, sosyal geri çekilme, olumlu izlenim bırakma ve genel sosyal onay ihtiyacı toplam puan ortalamalarında $Y$ ve $Z$ kuşaklarına bağlı anlamlı bir farklılık gözlenmiştir $(p<0,05)$. Z kuşağında yer alan katılımcıların; başkalarının duygularına duyarlılık, sosyal geri çekilme, olumlu izlenim bırakma ve genel sosyal onay ihtiyacı toplam puan ortalamaları anlamlı olarak daha yüksek bulunmuştur.

$\mathrm{Bu}$ doğrultuda H3a (Y ve Z kuşağı tüketicilerinin sosyal onay ihtiyaç düzeyleri anlamlı bir farklılık göstermektedir.) hipotezi desteklenmiştir. 


\section{A. T. Özden 11/3 (2019) 1537-1558}

Sosyal Onay İhtiyacı Ölçeği Puanlarının cinsiyete göre karşılaştırılması Tablo 13'de sunulmuştur.

Tablo 13. Sosyal Onay İhtiyacı Ölçeği Puanlarının Cinsiyete Göre Karşılaştırılması

\begin{tabular}{|c|c|c|c|c|c|c|c|}
\hline Değişken & Cinsiyet & $\mathrm{N}$ & $\bar{X}$ & Ss & $\mathrm{t}$ & $\mathrm{p}$ & Cohen $\mathrm{d}$ \\
\hline \multirow{2}{*}{$\begin{array}{l}\text { Başkalarının } \\
\text { Duyarlılık }\end{array}$} & Kadın & 189 & 3,04 & 1,23 & \multirow{2}{*}{1,74} & \multirow{2}{*}{0,08} & \multirow{2}{*}{0,17} \\
\hline & Erkek & 213 & 2,83 & 1,22 & & & \\
\hline \multirow{2}{*}{ Sosyal Geri Çekilme } & Kadın & 189 & 2,15 & 1,08 & \multirow{2}{*}{$-1,31$} & \multirow{2}{*}{0,19} & \multirow{2}{*}{0,13} \\
\hline & Erkek & 213 & 2,29 & 1,09 & & & \\
\hline \multirow{2}{*}{ Olumlu İzlenim Bırakma } & Kadın & 189 & 2,49 & 1,22 & \multirow{2}{*}{1,58} & \multirow{2}{*}{0,11} & \multirow{2}{*}{0,16} \\
\hline & Erkek & 213 & 2,30 & 1,17 & & & \\
\hline \multirow{2}{*}{ Sosyal onay ihtiyacı toplam } & Kadın & 189 & 2,58 & 1,08 & \multirow{2}{*}{0,86} & \multirow{2}{*}{0,39} & \multirow{2}{*}{0,09} \\
\hline & Erkek & 213 & 2,49 & 1,06 & & & \\
\hline
\end{tabular}

Tablo incelendiğinde, başkalarının duygularına duyarlılık, sosyal geri çekilme, olumlu izlenim bırakma ve genel sosyal onay ihtiyacı toplam puan ortalamalarında cinsiyete bağlı anlamlı bir farklılık gözlenmemiştir $(p>0,05)$. Araştırmaya katılımı sağlanan kadın ve erkeklerin başkalarının duygularına duyarlılık, sosyal geri çekilme, olumlu izlenim bırakma ve genel sosyal onay ihtiyacına yönelik algıları birbirine yakın bulunmuştur.

$\mathrm{Bu}$ doğrultuda $\mathrm{H} 3 \mathrm{~b}$ (Tüketicilerin sosyal onay ihtiyaç düzeyleri cinsiyete göre anlamlı bir farklılık göstermektedir.) hipotezi desteklenmemiştir.

Sosyal Onay İhtiyacı Ölçeği Puanlarının eğitim durumuna göre karşılaştırılması Tablo 14'de sunulmuştur.

Tablo 14. Sosyal Onay İhtiyacı Ölçeği Puanlarının Eğitim Durumuna Göre Karşılaştırılması

\begin{tabular}{|c|c|c|c|c|c|c|c|c|c|}
\hline Değişken & & Eğitim durumu & $\mathrm{N}$ & $\bar{X}$ & Ss & $\mathrm{F}$ & $\mathrm{p}$ & $\eta^{2}$ & Post-hoc \\
\hline \multirow{4}{*}{$\begin{array}{l}\text { Başkalarının } \\
\text { Duygularına } \\
\text { Duyarlılık }\end{array}$} & 1. & İlköğretim & 33 & 2,61 & 1,17 & \multirow{4}{*}{31,53} & \multirow{4}{*}{0,00} & \multirow{4}{*}{0,19} & \multirow{4}{*}{$\begin{array}{l}2>1, \quad 2>3, \quad 2>4 ; \quad 3>4, \\
1>4,\end{array}$} \\
\hline & 2. & Lise & 189 & 3,40 & 1,10 & & & & \\
\hline & 3. & Lisans & 131 & 2,76 & 1,21 & & & & \\
\hline & 4. & Lisansüstü & 49 & 1,76 & 0,80 & & & & \\
\hline \multirow{4}{*}{$\begin{array}{l}\text { Sosyal } \\
\text { Çekilme }\end{array}$} & 1. & İlköğretim & 33 & 2,46 & 1,30 & \multirow{4}{*}{12,22} & \multirow{4}{*}{0,00} & \multirow{4}{*}{0,08} & \multirow{4}{*}{$1>4 ; 2>4$} \\
\hline & 2. & Lise & 189 & 2,49 & 1,12 & & & & \\
\hline & 3. & Lisans & 131 & 1,99 & 0,91 & & & & \\
\hline & & Lisansüstü & 49 & 1,64 & 0,84 & & & & \\
\hline \multirow{4}{*}{$\begin{array}{l}\text { Olumlu } \\
\text { Birakma }\end{array}$} & 1. & İlköğretim & 33 & 2,55 & 1,21 & \multirow{4}{*}{20,18} & \multirow{4}{*}{0,00} & \multirow{4}{*}{0,13} & \multirow{4}{*}{$2>3,2>4 ; 1>4 ; 3>4$} \\
\hline & 2. & Lise & 189 & 2,78 & 1,24 & & & & \\
\hline & 3. & Lisans & 131 & 2,11 & 0,98 & & & & \\
\hline & & Lisansüstü & 49 & 1,54 & 0,87 & & & & \\
\hline \multirow{4}{*}{$\begin{array}{l}\text { Sosyal onay ihtiyaci } \\
\text { toplam }\end{array}$} & & İlköğretim & 33 & 2,54 & 1,15 & \multirow{4}{*}{24,76} & \multirow{4}{*}{0,00} & \multirow{4}{*}{0,16} & \multirow{4}{*}{$2>3,2>4 ; 1>4 ; 3>4$} \\
\hline & & Lise & 189 & 2,91 & 1,03 & & & & \\
\hline & & Lisans & 131 & 2,31 & 0,95 & & & & \\
\hline & 4. & Lisansüstü & 49 & 1,65 & 0,80 & & & & \\
\hline
\end{tabular}

Tablo incelendiğinde, başkalarının duygularına duyarlılık, sosyal geri çekilme, olumlu izlenim bırakma ve genel sosyal onay ihtiyacı toplam puan ortalamalarında eğitim durumuna bağlı anlamlı bir farklılık gözlenmiştir $(p<0,05)$. Genel olarak, ilköğretim ve lise mezunu katılımcıların; başkalarının duygularına 


\section{A. T. Özden 11/3 (2019) 1537-1558}

duyarlılık, sosyal geri çekilme, olumlu izlenim bırakma ve genel sosyal onay ihtiyacı toplam puan ortalamaları daha yüksek, lisansüstü mezunu katılımcıların; başkalarının duygularına duyarlılık, sosyal geri çekilme, olumlu izlenim bırakma ve genel sosyal onay ihtiyacı toplam puan ortalamaları ise daha düşük bulunmuştur.

Bu doğrultuda H3c (Tüketicilerin sosyal onay ihtiyaç düzeyleri eğitim seviyesine göre anlamlı bir farklılık göstermektedir.) hipotezi desteklenmiştir.

Sosyal Onay İhtiyacı Ölçeği Puanlarının aylık bireysel gelir durumuna göre karşılaştıılması Tablo 15'de sunulmuştur.

Tablo 15. Sosyal Onay İhtiyacı Ölçeği Puanlarının Aylık Bireysel Gelir Durumuna Göre Karşılaştırılması

\begin{tabular}{|c|c|c|c|c|c|c|c|c|c|}
\hline Değişken & & bireysel & $\mathrm{N}$ & $\bar{X}$ & Ss & F & $\mathrm{p}$ & $\eta^{2}$ & Post-hoc \\
\hline \multirow{5}{*}{$\begin{array}{l}\text { Başkalarının } \\
\text { Duygularına } \\
\text { Duyarlılık }\end{array}$} & 1. & 2000 TL'den az & 149 & 3,42 & 1,04 & \multirow{5}{*}{17,63} & \multirow{5}{*}{0,00} & \multirow{5}{*}{0,15} & \multirow{5}{*}{$\begin{array}{l}1>4,1>5 ; 2>4,2>5 \\
3>4 ;\end{array}$} \\
\hline & 2. & 2001-5000 TL & 116 & 2,87 & 1,22 & & & & \\
\hline & 3. & 5001-8000 TL & 81 & 2,76 & 1,24 & & & & \\
\hline & 4. & $8001-11000 \mathrm{TL}$ & 33 & 1,84 & 0,84 & & & & \\
\hline & 5. & 11000 TL üzeri & 23 & 2,16 & 1,33 & & & & \\
\hline \multirow{5}{*}{$\begin{array}{l}\text { Sosyal Geri } \\
\text { Çekilme }\end{array}$} & 1. & 2000 TL'den az & 149 & 2,46 & 1,09 & \multirow{5}{*}{5,60} & \multirow{5}{*}{0,00} & \multirow{5}{*}{0,05} & \multirow{5}{*}{$1>4,2>4$} \\
\hline & 2. & 2001-5000 TL & 116 & 2,24 & 1,12 & & & & \\
\hline & 3. & 5001-8000 TL & 81 & 2,10 & 1,02 & & & & \\
\hline & 4. & $8001-11000 \mathrm{TL}$ & 33 & 1,56 & 0,63 & & & & \\
\hline & 5. & 11000 TL üzeri & 23 & 2,01 & 1,18 & & & & \\
\hline \multirow{5}{*}{$\begin{array}{l}\text { Olumlu } \\
\text { İzlenim } \\
\text { Birakma }\end{array}$} & 1. & 2000 TL'den az & 149 & 2,77 & 1,15 & \multirow{5}{*}{9,81} & \multirow{5}{*}{0,00} & \multirow{5}{*}{0,09} & \multirow{5}{*}{$1>5,1>4 ; 2>4$} \\
\hline & 2. & 2001-5000 TL & 116 & 2,38 & 1,25 & & & & \\
\hline & 3. & 5001-8000 TL & 81 & 2,19 & 1,09 & & & & \\
\hline & 4. & $8001-11000 \mathrm{TL}$ & 33 & 1,58 & 0,78 & & & & \\
\hline & 5. & 11000 TL üzeri & 23 & 1,89 & 1,22 & & & & \\
\hline \multirow{5}{*}{$\begin{array}{l}\text { Sosyal onay } \\
\text { ihtiyacı } \\
\text { toplam }\end{array}$} & 1. & 2000 TL'den az & 149 & 2,90 & 0,95 & \multirow{5}{*}{13,04} & \multirow{5}{*}{0,00} & \multirow{5}{*}{0,12} & \multirow{5}{*}{$1>4,1>5 ; 2>4 ; 3>4$} \\
\hline & 2. & 2001-5000 TL & 116 & 2,51 & 1,11 & & & & \\
\hline & 3. & 5001-8000 TL & 81 & 2,37 & 1,03 & & & & \\
\hline & 4. & $8001-11000 \mathrm{TL}$ & 33 & 1,67 & 0,70 & & & & \\
\hline & 5. & 11000 TL üzeri & 23 & 2,02 & 1,19 & & & & \\
\hline
\end{tabular}

Tablo incelendiğinde, başkalarının duygularına duyarlılık, sosyal geri çekilme, olumlu izlenim bırakma ve genel sosyal onay ihtiyacı toplam puan ortalamalarında aylık bireysel gelir durumuna bağlı anlamlı bir farklılık gözlenmiştir ( $\mathrm{p}<0,05)$. Genel olarak, aylık gelirinin "2000 TL'den az" ve "2001-5000 TL" olduğunu belirten katılımcıların; başkalarının duygularına duyarlılık, sosyal geri çekilme, olumlu izlenim bırakma ve genel sosyal onay ihtiyacı toplam puan ortalamaları daha yüksek, aylık gelirinin "8001 - 11000 TL" olduğunu belirten katılımcıların; başkalarının duygularına duyarlılık, sosyal geri çekilme, olumlu izlenim bırakma ve genel sosyal onay ihtiyacı toplam puan ortalamaları ise daha düşük bulunmuştur.

$\mathrm{Bu}$ doğrultuda H3d (Tüketicilerin sosyal onay ihtiyaç düzeyleri gelir durumuna göre anlamlı bir farklılık göstermektedir.) hipotezi desteklenmiştir.

\section{Sonuç ve Öneriler}

Tüketicilerin, içinde yaşadıkları topluma kendilerini ait hissedebilmeleri ve bu toplumda kabul görebilmeleri için çeşitli norm ve davranış kurallarına uymaları gerekmektedir. Günümüz tüketim 


\section{A. T. Özden 11/3 (2019) 1537-1558}

toplumlarında bu durum kimi zaman tüketicilerin tükettikleri ürünler aracılığıyla elde edilmektedir. Tüketiciler, tükettikleri ürünlerin sembolik anlamları ile yaşadıkları toplum tarafından daha çok kabul görebilmekte, statü ve prestij kazanabilmektedirler. Özellikle teknoloji ve onun getirdiği olanaklar ile çok fazla etkileşim halinde olan tüketicilerin sosyal onay ihtiyaç düzeylerinin yenilikçi eğilimlerini etkileme şeklinin, pazara yeni bir ürün sunacak olan işletmelerin hedef pazarlarını tanımalarını kolaylaştıracak önemli ölçütlerden biri olduğu düşünülmektedir. Nitekim tüketicilerin yenilikçi eğilimlerinin başarılı bir şekilde tespit edilmesi pazara sunulacak yeni ürünün başarısını artıracaktır (Goldsmith vd., 1998: 350). Tüketicilerin sosyal onay ihtiyaç düzeylerinin yenilikçi eğilimleri üzerindeki etkisinin, $\mathrm{Y}$ ve $\mathrm{Z}$ kuşağına mensup olanların karşılaştırılması yapılarak ele alındığ ${ }_{1}$ bu çalışmada, tüketicilerin sosyal onay ihtiyaç düzeylerinin yenilikçi eğilimleri üzerinde etkisi olduğu, sosyal onay ihtiyaç düzeyi arttıkça tüketici yenilikçi eğiliminin arttığı görülmüştür. Tüketicilerin, yeni ürün kullanarak çevreleri tarafından daha kolay kabul görebildiklerini düşündükleri söylenilebilir.

$\mathrm{Bu}$ çalışmada, Z kuşağına mensup tüketicilerin, $\mathrm{Y}$ kuşağına mensup tüketicilere göre sosyal onay ihtiyaçlarının ve yenilikçi eğilimlerinin daha yüksek olduğu tespit edilmiştir. Benzer şekilde Im vd. (2003), Leung (1998), Steenkamp vd. (1999), yapmış oldukları araştırmada genç tüketicilerin daha yenilikçi olduğunu tespit etmişlerdir. $Y$ ve $Z$ kuşağına mensup tüketicilerin, teknolojinin hızlı gelişimine ve getirdiği toplumsal değişimlere uyum sağlayabilme şekilleri ve tüketim alışkanlıkları açısından farklılıklar gösterdiği söylenilebilir. Z kuşağındaki tüketicilerin, teknolojinin ve getirdiği yeniliklerin içine doğduklarından yeniliklere daha açık oldukları ve yenilik anlamında beklentilerinin daha yüksek olduğu düşünülmektedir. Ayrıca Z kuşağındaki tüketicilerin en büyügünün 19 yaşında ve çoğunluğu henüz ergenlik sürecinde olmalarının ve $Y$ kuşağındaki tüketicilerin ise iş hayatına atılmış ve yetişkin olmalarının sosyal onay ihtiyaç düzeylerinin farklılaşma sebepleri arasında olduğu söylenilebilir. Dolayısıyla yeni ürünler için potansiyel alıcıların belirlenebilmesi için tüketici yenilikçiğinin davranışsal bir pazar bölümlendirmesi sunması yeterli değildir (Akdoğan ve Karaaslan, 2013: 15). Bu nedenle tüketicilerin yenilikçi eğilimlerini etkileyen psikolojik faktörlerin ve kuşaklar arasındaki farklılaşmalarının ele alınması pazar bölümlendirme ve isabetli hedef pazar belirlenebilmesi açısından önem taşımaktadır.

Tüketici yenilikçiliği ile cinsiyet arasındaki ilişki incelendiğinde kadın tüketicilerin hedonik yenilikçi eğilimlerinin daha yüksek olduğu görülmüştür. Kadın tüketicilerin erkek tüketicilere göre daha yüksek hedonik güdülerle satın alım yaptığı görülmektedir (Scherhorn, vd., 1990; Arnold ve Reynolds, 2003). Bu nedenle kadın tüketicilerin hedonik yenilikçi eğilimi gösterdikleri söylenilebilir. Araştırmada elde edilen bir diğer sonuca göre, lisansüstü eğitim seviyesinde olan tüketicilerin en düşük, lise eğitim seviyesindeki tüketicilerin en yüksek yenilikçi eğilim gösterdikleri, düşük gelirli tüketicilerin yüksek yenilikçi eğilim gösterdikleri görülmektedir. Tüketici yenilikçiği ile ilgili yapılan çalışmalarda tüketicilerin eğitim seviyesi ve gelir durumları ile ilgili farklı sonuçlar elde edildiği görülmektedir. Im vd. (2003), Özçiftçi (2015), Shih ve Venkatesh (2004) yüksek geliri olanların daha yenilikçi olduğunu belirtirlerken, Sttenkamp vd. (1999) ise yenilikçilik ve gelir durumu arasında bir ilişki olmadığını belirtmektedirler. Midgley ve Dowling (1993) ve Steenkamp vd. (1999) daha eğitimli tüketicilerin daha yüksek yenilikçi eğilim gösterdiğini tespit etmişlerdir. Bu araştırmada ise düşük eğitim seviyesi ve düşük gelir durumu olan tüketicilerin sosyal onay ihtiyaçlarının daha yüksek oluşunun yenilikçi eğilimlerini etkilediği düşünülmektedir.

İşletmelerin başarılı strateji geliştirmelerinin yolu, hedef kitleyi doğru tespit edebilmekten ve pazar bölümlendirmeyi isabetli yapabilmekten geçmektedir. Bu anlamda işletmelerin, günümüzün ve geleceğin tüketicilerinin önemli bir kısmını oluşturan $Y$ ve $Z$ kuşağı tüketicilerini yakından tanınmaları ve bu tüketicilerin yeni üründen beklentilerini tespit etmeleri gerekmektedir. Toplum tarafından kabul görme ve onay alma ihtiyaç düzeyinin tespiti ve pazara sunulan yeni ürünün bu ihtiyacı ne düzeyde tatmin ettiğinin belirlenmesinin, günümüz tüketim toplumlarında etkili işletmeler olabilmek için önemli doneler içerdiği düşünülmektedir. Nitekim günümüzde ürünler, fonksiyonel faydalarından ziyade taşıdıkları sembolik anlamlar nedeniyle tüketiciler için toplumda kabul görme araçları haline dönüşmeye başlamışlardır.

Bu çalışmada elde edilen bulgular ışığında aşağıda verilen öneriler geliştirilmiştir:

- Pazara sunulacak yeni bir ürün söz konusu olduğunda yenilikçi tüketicilerin tespit edilmesinin, bu ürünün hedef pazardaki başarısını artıracağı düşünülmektedir. Nitekim yenilikçi eğilimi yüksek olan tüketiciler, yeni ürünleri daha çok takip etmektedirler ve yenilikleri daha kolay benimsemektedirler. 


\section{A. T. Özden 11/3 (2019) 1537-1558}

Dolayısıyla yenilikçi eğilimi olan tüketiciler çevrelerine referans olma açısından diğer tüketicilere göre daha erken hareket etmektedirler.

- Tüketicilerin yenilikçi eğilim düzeylerinin ve bunu etkileyen özelliklerin tespit edilmesi, işletmelerin hedef kitlelerinin yeni ürün ile hangi özelliğinin ön plana çıkartılacağı açısından önem taşımaktadır. Sosyal onay ihtiyacı yüksek tüketiciler için pazara sunulacak yeni ürünün kendini gösterme, statü veya prestij kazandırma, olumlu izlenim bırakma gibi özelliklerinin ön plana çıartılması, işletmelerin başarılı olmasını sağlayacaktır.

- Örneklem bakımından Ankara ve Samsun şehirlerini kapsaması ve sadece $Y$ ve Z kuşağından olan tüketicilerle yürütülmüş olması bu araştırmanın kısıtı olarak değerlendirilmektedir. Sosyal onay ihtiyacı ve tüketici yenilikçiliği arasındaki ilişkinin her yaştaki tüketiciler için ve farklı bölgelerden farklı şehirlerden olan tüketicilerle ele alınmasının işletmeler ve uygulayıcılar açısından daha aydınlatıcı olacağı düşünülmektedir. Ayrıca tüketici yenilikçiliğini etkileyen farklı psikolojik faktörlerin ele alınarak araştııılmasının ve sektör bazında tüketicilerin yenilikçi eğilimlerinin tespit edilmesinin pazar bölümlendirmede işletmelere kolaylık sağlayacağı düşünülmektedir.

\section{Kaynakça}

Akdoğan, Ş., Uyar, K. ve Güllü, K. (2018). Profiles of consumer innovativeness in Turkey, Journal of Management, Marketing and Logistics, 5 (3), 236-245.

Akdoğan, Ş. ve Karaaslan, M. H. (2013). Tüketici yenilikçiliği, Atatürk Üniversitesi İktisadi ve İdari Bilimler Dergisi, 27 (2): 1-20.

Alan, H. ve Yeloğlu, O. (2013). Markalaşma ve yenilikçilik, Siirt Üniversitesi İktisadi ve İdari Bilimler Fakültesi İktisadi Yenilik Dergisi, 1 (1), 13-26.

Altıntuğ, N. (2012). Kuşaktan kuşağa tüketim olgusu ve geleceğin tüketici profili, Organizasyon ve Yönetim Bilimleri Dergisi. 4 (1), 203-212.

Arnold, M. J. ve Reynolds, K. E. (2003). Hedonic shopping motivations, Journal of Retailing, 79 (2), 77-95.

Aydın, S. (2009). Kişisel ve ürün temelli yenilikçilik: cep telefonu kullanıcıları üzerine ampirik bir uygulama, Doğuş Üniversitesi Dergisi, 10 (2), 188-203

Bartels J. ve Reinders, M. J. (2011). Consumer innovativeness and its correlates: a propositional inventory for future research, Journal of Business Research, 64, 601-609.

Bülbül, H. ve Özoğlu, B. (2014). Tüketici yenilikçiliği ve algılanan riskin satın alma davranışına etkisi, Erciyes Üniversitesi İktisadi ve İdari Bilimler Fakültesi Dergisi, 44, 43-58

Büyüköztürk, Ş., Şekercioğlu, G. ve Çokluk, O. (2012). Sosyal bilimler için çok değişkenli SPSS ve LISREL uygulamaları (Ankara: Pegem Akademi Yayıncilık).

Cestre, G. ve Darmon, R. Y. (1998). Assessing consumer preferences in the context of new product diffusion, International Journal of Research in Marketing, 15 (2), 123-135.

Citrin, A. V., Sprott, D. E., Silverman, S. ve Stem, D. (2000). Adoption of internet shopping: the role of consumer innovativeness, Industrial ManagementEData Systems, 100 (7), 294-300.

Clark, R. ve Goldsmith, R. (2006). Interpersonal influence and consumer innovativeness, International Journal of Consumer Studies, 30 (1), 34-43.

Daghfous, N., Petrof, J. V. ve Pons, F. (1999). Values and adoption of innovations: a crosscultural study, Journal of Consumer Marketing, 16 (4), 314-331.

Demirelli, C. (2014). Tüketici yenilikçiliği ve gönüllü sade yaşam tarzı arasındaki ilişkinin incelenmesi, Yönetim ve Ekonomi Araştırmaları Dergisi, 24, 320-337.

Deniz, A. ve Erciş, A. (2016). Tüketici yenilikçiliğinin boyutları ve yenilikçiliği etkileyen faktörler arasındaki ilişkiler, Kafkas Üniversitesi İktisadi ve İdari Bilimler Fakültesi Dergisi, 7 (14), 461-475.

DeVaney, S. A. (2015). Understanding the millennial generation, Society of Financial Service Professionals. 69 (6), 1-14. 


\section{A. T. Özden 11/3 (2019) 1537-1558}

Dobre, C., Dragomir, A. ve Preda, G. (2009). Consumer ınnovatıveness: a marketıng approach, Management $\mathcal{E}$ Marketing, 4 (2), 19-34.

Erciş, A. ve Türk, B. (2014). Kişisel değerler ve içsel yenilikçilik boyutları ilişkisinin yapısal eşitlik modeliyle incelenmesi, Atatürk Üniversitesi İktisadi ve İdari Bilimler Dergisi, 28 (2), 75- 88.

Eryiğit, C. ve Kavak, B. (2008). Yeniliği erken ve geç benimseyenler ile benimsemeyenlerin demografik özelliklerinin ve yaşam arzlarının yayılma modelleri yardımılla tanımlanması, Pazarlama ve Pazarlama Araştırmaları Dergisi, 3, 21-43 22.

Eryiğit, C. ve Kavak, B. (2011). Tüketici yenilikçiliğinin tutumsal ve davranışsal uyumunun incelenmesi, H.Ü. İktisadi ve İdari Bilimler Fakültesi Dergisi, 29 (2), 95-113.

Esen, Ü., Esen, F. ve Yıldırım, Ş. S. (2018). Kültür boyutları ile online alışveriş davranışı arasındaki ilişkide bireysel yenilikçilik ve güvenin aracılık etkisi, Uluslararası Yönetim İktisat ve İşletme Dergisi, 14 (1), 257282.

Fuentes-Blasco, M., Velazquez, B. M., Francez, D. S. ve Gil-Saura, I. (2017). Role of marketing and technological innovation on store equity, satisfaction and word-of-mouth in retailing, Journal of Product $\mathcal{E}$ Brand Management, 26 (6), 650-666.

George, D. ve Mallery, P. (2010). SPSS for Windows Step by Step: A Simple Guide and Reference, 17.0 Update, Boston, Pearson.

Goldsmith, R. E. ve Hofacker, C. F. (1991). Measuring consumer innovativeness, Journal of the Academy of Marketing Science, 19(3), 209-221.

Goldsmith, R. E. ve Newell, S. J. (1997). Innovativeness and price sensitivity: managerial, theoretical and methodological issues, Journal of Product E Brand Management, 6(3), 163 -174.

Goldsmith, R. E., Moore, M. A. ve Beaudoin, P. (1999). Fashion innovativeness and self-concept: a replication, Journal of Product $\mathcal{E}$ Brand Management, 8 (1), 7-18.

Grewal, R., Mehta, R. ve Kardes, F. R. (2000). The Role of the social-1dentity function of attitudes in consumer innovativeness and opinion leadership, Journal of Economic Psychology, 21 (3), 233-252

Hasan, R., Lowe, B. ve Petrovici, D. (2019). An empirical comparison of consumer innovation adoption models: implications for subsistence marketplaces, Journal of Public PolicyEMarketing, 38 (1), 61-80.

Hirschman, E. C. (1980). Innovativeness, novelty seeking and consumer creativity, Journal Of Consumer Research, 7, 83-295.

Im, S., Bayus, B. L. ve Mason, C. (2003). An empirical study of innate consumer innovativeness, personal characteristics, and new product adoption behavior, Journal of the Academy of Marketing Science, 31 (1), 61-73.

Im, S., Mason, C. ve Houston, M. B. (2007). Does innate consumer innovativeness relate to new product/service adoption behavior? the intervening role of social learning via vicarious innovativeness, Journal of the Academic Marketing Science, 35, 63-75.

Jordaan, Y. ve Simpson, M. (2006). Consumer innovativeness among females in specific fashion stores in the menlyn shopping centre, Journal of Family Ecology and Consumer Sciences, 34, 32-40.

Kadıoğlu, Z. (2013). Kitle iletişim araçlarının şekillendirdiği sosyal kimlikler ve aidiyet duygusu ekseninde tüketici davranışları, İstanbul Üniversitesi İletişim Fakültesi Dergisi, 2 (45), 101-114

Karaşar, B. ve Öğülmüş, S. (2016a). Üniversite öğrencilerinde sosyal onay ihtiyacının çeşitli değişkenler açısından incelenmesi, Uludă̆ Üniversitesi Eğitim Fakültesi Dergisi, 29 (2), 469-495

Karaşar, B. ve Öğülmüş, S. (2016b), Sosyal onay ihtiyacı ölçeği: geçerlik ve güvenirlik analizi, Ege Ĕ̆itim Dergisi, (17) 1, 84-104 


\section{A. T. Özden 11/3 (2019) 1537-1558}

Kavak, B., Sunaoğlu, Ş. K. ve Taner, N. (2017). Yeniliği benimseyen kategorilerinin bütüncül ve analitik düşünme açısından farklılıkları:akıllı telefonlar için bir inceleme, Pazarlama ve Pazarlama Araştırmaları Dergisi, 20, 179-200

Kavak, B., Taner, N. ve Kazancı, Ş. (2016). Yeniliği benimseyen kategorilerinin yenilikçi davranış güdüleri açısından farklılıkları: akıllı telefon kullanıcıları üzerinde bir inceleme, Pazarlama Teorisi ve Uygulamaları Dergisi, 2 (2), 91-121.

Kılıçer, K. ve Odabaşı, F. H. (2010). Bireysel yenilikçilik ölçeği (BYÖ): Türkçeye uyarlama, geçerlik ve güvenirlik çalışması, Hacettepe Üniversitesi Ĕ̆itim Fakültesi Dergisi, 38, 150-164.

Kline, R. B. (2011). Convergence of structural equation modeling and multilevel modeling, Williams, M. ve Vogt, W. P. (Ed.) Handbook Of Methodological Innovation, Thousand Oaks, CA: Sage, 562-589.

Köker, N. E. ve Maden, D. (2017). Tüketici yenilikçiliğinin, öz saygı ve sosyal kimlik boyutları temelinde incelenmesi: italya ve türkiye üzerine bir araştırma, Hitit Üniversitesi Sosyal Bilimler Enstitüsü Dergisi, $10(2), 835-853$.

Kumar, V. (2014). Understanding cultural differences in innovation: A conceptual framework and future research directions, Journal of International Marketing, 22 (3), 1-29.

Lassar, W. M., Manolıs, C. ve Lassar, S. (2005). The relationship between consumer innovativeness, personel charactaristics and online banking adoption, International Journal Of Bank Marketing, 23 (2), 176-199.

Leibenstein, H. (1950). Bandwagon, snob and veblen effects in the theory of consumers' demand, Quarterly Journal of Economics, 64, 183-207.

Leite, W. L. ve Beretvas, N. (2005). Validation of scores on the marlowe-crowne social desirability scale and the balanced inventory of desirable responding, Educational and Psychological Measurement, 65, 140-154.

Leung, L. (1998). Lifestyles and the use of new media technology in urban China, Telecommunications Policy, $22(9), 781-90$.

Madran, C. ve Esen, K. (2002), Yeniliklerin kabul süreci; üniversite öğrencileri ile yapılan bir pilot çalışma, Çukurova Üniversitesi Sosyal Bilimler Enstitüsü Dergisi, 9 (9), 136-152.

Manning K .C., Bearden, W. O. ve Madden, T. (1995). Consumer innovativeness and the adoption process, Journal of Consumer Psychology, 4 (4), 329-345.

Masterson, M. L. (1971). Family structure variables and need approval, Journal Of Consulting And Clinical Psychology, 36(1), 12-13.

Midgley, D. F. ve Dowling, G. R. (1993). A longitudinal study of product form innovation: the interaction between predisposition and social messages, Journal of Consumer Research, 19 (4), 611-625.

Midgley, D. F. ve Dowling, G. R. (1978). Innovativeness: the concept and its measurement, Journal of Consumer Research, 4 (4), 229-242.

Okutan, S., Bora, B. ve Altunışık, R. (2013). Keşifsel satın alma eğilimleri ve bu eğilimlerin plansız, kompülsif ve hedonik satın alma tarzlarıyla olan ilişkisinin incelenmesi, Eskişehir Osmangazi Üniversitesi İ̈BF Dergisi, 8(3), 117- 136

Özçiftçi, V. (2015). Tüketici yenilikçiliği ve moda yenilikçiliği ilişkisinin incelenmesi, Social Sciences, 10 (4), 135-148.

Persaud, A. ve Azhar, İ. (2012). Innovative mobile marketing via smartphones: Are consumers ready?, Marketing Intelligence \& Planning, 30 (4), 418-443.

Scherhorn, G., Reisch, L. R. ve Raab, G. (1990). Addictive buying in West Germany: An emprical study, Journal of Consumer Policy, 13 (4), 355-387.

Shih, C. F. ve Venkatesh, A. (2004). Beyond adoption development andapplication of a use-diffusion model, Journal of Marketing, 68 (1), 59-72. 


\section{A. T. Özden 11/3 (2019) 1537-1558}

Steenkamp, J-B. E.M., Hofstede, F. T.ve Wedel, M. (1999). A cross-national investigation in to the individual and national cultural antecedents of consumer innovativeness, Journal of Marketing, 63 (2), 55-69.

Stock, R. M., Hippel, E. ve Gillert, N. L. (2016). Impacts of personality traits on consumer innovation success, Research Policy, 45 (4), 757-769.

Tavşancıl, Ezel (2005). Tutumların ölçülmesi ve SPSS ile veri analizi, Ankara, Nobel Yayın Dağıtım

Tek, B. Ö. ve Engin, Ö. (2005). Modern pazarlama ilkeleri, İzmir, Birleşik Matbaacıllk

Tellis, G., Yin, E. ve Bell, S. (2009). Global consumer innovativeness: cross-country differences and demographic commonalities, Journal of International Marketing, 17 (2), 1-22.

Tripsas, M. (2008). Customer preference discontinuities: a trigger for radical technological change, Managerial and Decision Economics, 29, 79-97.

Türk Dil Kurumu (2019). Yenilik Nedir?, http://tdk.gov.tr/index.php?option=com gts\&arama=gts\&guid=TDK.GTS.5c7cc18067a9a6.28097070 (Erişim Tarihi: 10.02.2019).

Twenge, J. M. ve Campbell, S. M. (2008). Generational differences in mpsychological traits and their impact on the workplace, Journal of Managerial Psychology, 23 (8), 862-877.

Uzkurt, C. (2007). Tüketicilerin yenilikleri benimseme eğilimleri üzerinde kişisel değerlerin etkisi, Anadolu Üniversitesi Sosyal Bilimler Dergisi, 7 (2), 241-260

Vandecasteele, B. ve Geuens, M. (2010). Motivated consumer innovativeness: concept, measurement, and validation, Intern. J. of Research in Marketing, 27, 308-318.

Venkatraman, M. P. (1991). The impact of innovativeness and innovation type on adoption, Journal of Retailing, 67 (1), 51-68

Venkatraman, M. P. ve Price L. L. (1990). Differentiating between cognitive and sensory innovativeness: concepts, Measurement And Their Implications Journal of Business Research, 20, 293-315.

Wang, C. ve Yang, H. (2008). Passion for online shopping: the influence of personality and compulsive buying, Social Behavior and Personality, 36 (5), 693-706.

West, H. (2013). Fear is not a mental disorder: or what is really wrong with the dsm http://www.harperwest.co/fear-is-not-a-mental-disorderor-what-is-really-wrong-with-the-dsm/ (Erişim Tarihi: 12.02.2019).

Yaşa, E. ve Bozyiğit, S. (2012). Y kuşağı tüketicilerinin cep telefonu ve gsm operatörleri tercihi: Mersin ilindeki üniversite öğrencilerinin tercihlerini belirlemeye yönelik pilot bir araştırma, Çă̆ Üniversitesi Sosyal Bilimler Dergisi. 9(1), 29-46. 